\title{
Rapid characterisation of the extremely large landslide threatening the Rules Reservoir (Southern Spain)
}

Cristina Reyes-Carmona ${ }^{1,2^{*}}$, Jorge Pedro Galve ${ }^{2}$, Marcos Moreno-Sánchez ${ }^{2}$, Adrián Riquelme ${ }^{3}$, Patricia Ruano ${ }^{2,4}$, Agustín Millares ${ }^{5}$, Teresa Teixidó6, Roberto Sarro ${ }^{1}$, José Vicente PérezPeña ${ }^{2,6}$, Anna Barra ${ }^{7}$, Pablo Ezquerro ${ }^{1,8}$, Juan López-Vinielles ${ }^{1,8,9}$, Marta Béjar-Pizarro ${ }^{1}$, José Miguel Azañón ${ }^{2,4,6}$, Oriol Monserrat ${ }^{7}$, Rosa María Mateos ${ }^{1}$

"corresponding author, email: c.reyes@igme.es

${ }^{1}$ Geohazards InSAR Laboratory and Modelling Group (InSARlab), Geoscience Research Department, Geological Survey of Spain (IGME), Calle de Ríos Rosas 23, 28003 Madrid, Spain

${ }^{2}$ Departament of Geodynamics, University of Granada, Avenida del Hospicio s/n, 18010 Granada, Spain

${ }^{3}$ Department of Civil Engineering, University of Alicante, Carrer de San Vicente del Raspeig s/n, 03690 San Vicente del Raspeig, Spain

${ }^{4}$ Instituto Andaluz de Ciencias de la Tierra (IACT-CSIC), Avenida de las Palmeras 4, 18100 Armilla, Granada, Spain

${ }^{5}$ Instituto Interuniversitario de Investigación del Sistema Tierra en Andalucía (IISTA), Avenida del Mediterráneo s/n, 18006 Granada, Spain

${ }^{6}$ Instituto Universitario de Investigación Andaluz de Geofísica y Prevención de Desastres Sísmicos (IAG), Campus Universitario de Cartuja, 18071 Granada, Spain

${ }^{7}$ Geomatics Division, Centre Tecnològic de Telecomunicacions de Catalunya (CTTC/CERCA), Avinguda Carl Friedrich Gauss 7, 08860 Castelldefels, Spain

${ }^{8}$ Escuela Técnica Superior de Ingenieros de Caminos, Canales y Puertos, Universidad Politécnica de Madrid, Madrid, Spain

${ }^{9}$ HEMAV SL, Carrer d'Esteve Terrades 1, 08860 Castelldefels, Spain

This is a a non-peer reviewed preprint of the article that has just been published in Landslides.

DOI: https://doi.org/10.1007/s10346-021-01728-z 


\begin{abstract}
When an active landslide is first identified in an artificial reservoir, a comprehensive study has to be quickly conducted to analyse the possible hazard that it may represent to such a critical infrastructure. This paper presents the case of the El Arrecife Landslide, located in a slope of the Rules Reservoir (Southern Spain), as an example of geological and motion data integration for elaborating a preliminary hazard assessment. For this purpose, a field survey was carried out to define the kinematics of the landslide: translational in favour of a specific foliation set, and rotational at the foot of the landslide. A possible failure surface has been proposed, as well as an estimation of the volume of the landslide: 14.7 million $\mathrm{m}^{3}$. At the same time, remote sensing and geophysical techniques were applied to obtain historical displacement rates. A mean subsidence rate of up to $2 \mathrm{~cm} / \mathrm{yr}$ was obtained by means of Synthetic Aperture Radar Interferometry (InSAR) and Ground Penetrating Radar (GPR) data, during the last 5 and 22 years, respectively. The Structure-from-Motion (SfM) technique provided a higher rate, up to 26 $\mathrm{cm} / \mathrm{yr}$ during the last 14 years, due to compaction of a slag heap located within the foot of the landslide. All of this collected information will be valuable to optimise the planning of future monitoring surveys (i.e. Differential Global Positioning Systems, inclinometers, ground drilling and InSAR) that should be applied in order to prevent further damage on the reservoir and related infrastructures.
\end{abstract}

\title{
Keywords
}

Landslide, Reservoir, Quick hazard assessment, Geological data, Multi-technique monitoring, InSAR, SfM, GPR

\section{Introduction}

The study of a specific landslide must start with a geological and geomorphological characterisation to define its main attributes, such as dimensions, structure, geometry, or volume (Cruden and Varnes 1996). This knowledge is an essential starting point for not only planning and optimising monitoring surveys, but also to provide a conceptual model for modelling the slope. Monitoring surveys are a key component of most landslide hazard assessments, and they typically involve obtaining surface displacement rates measured over time (Clague and Stead 2012). Additionally, the temporal displacement patterns can be analysed to detect critical accelerations that may precede a catastrophic failure of the slope (Carlà et al. 2019). Characterising and monitoring a landslide is even more important when it takes place in a reservoir, where landslides usually lead to risky situations that may result in human, material and/or economic losses (e.g. Kiersch 1964; Schuster 1979; Spanilá et al. 2002; Wang et al. 2004; Gutiérrez et al. 2010; Reyes-Carmona et al. 2020a). Because these are such critical infrastructures, the monitoring techniques employed must use already registered information to provide quick results with which to rapidly evaluate the possible landslide impacts on the reservoir. These requirements are also important to consider in case of an alarm situation.

Currently, there is a wide range of techniques that provide ground surface displacement data related to landslide activity: i) remote sensing techniques, that include Synthetic Aperture Radar Interferometry (InSAR) (e.g. Massonet and Feigl 1998), Global Positioning Systems (GPS) (e.g. Brunner and Gassner 2003), Terrestrial Laser Scanner (TLS) (e.g. Teza et al. 2007), and photogrammetry using aerial photographs from planes (e.g. Kraus, 1997) or Remotely Piloted Aircraft Systems (RPAS) (e.g. Niethammer et al. 2012); ii) geophysical techniques, such as Ground Penetrating Radar (GPR) (e.g. Lissak et al. 2015), or iii) conventional geotechnical monitoring systems like inclinometers or extensometers (e.g. Corominas et al. 2000).

Only a few of these techniques can be applied to retrospectively quantify a landslide displacement rate by using already registered information: (1) InSAR applied to archived radar satellite images, and (2) photogrammetry of historic aerial photographs. Moreover, the mentioned techniques can be used very quickly to obtain preliminary data that may guide the subsequent studies, or monitoring surveys, over a landslide. Regarding InSAR methods as the Geohazards Exploitation Platform (GEP) of the European Space Agency (ESA) can provide Earth surface velocity maps in just 24-48 hours (e.g. Manunta et al. 2016; Galve et al. 2017; 
Tapete and Cigna 2017; Foumelis et al. 2019; Reyes-Carmona et al. 2020b). On the other hand, Structure-from-Motion (SfM) techniques (Ullman 1979; Hartley and Zisserman 2003; Szeliski 2010; Fisher et al. 2013) allow one to generate landscape 3D models to identify the evolution of landforms with historical aerial photographs, in a short period of time, by comparing at least two different Digital Elevation Models (DEMs) at different dates (Snavely et al. 2008; Westoby et al. 2012; Eltner et al. 2016; Riquelme et al. 2019). In case of a landslide, the quantified changes can be attributed to its activity, making it possible to estimate the displacement rate during a certain period of time.

Additionally, if a road crosses an active landslide, the infrastructure can also record old displacements that may have been covered by resurfacing works. In such cases, a one-day Ground Penetrating Radar (GPR) survey can be carried out to obtain cross-sections along the road that can, then, be used to identify the sequence of asphalt layers. With this system, the vertical displacement rate along a road can be inferred from the evolution of the asphalt layering with time (e.g., Lissak et al. 2015).

In this paper, the methods above have been integrated in the study of the El Arrecife Landslide (Fig. 1), a landslide recently recognised by DInSAR techniques (Reyes-Carmona et al. 2020a). This landslide affects the western slope of the Rules Reservoir (Southern Spain), which leads to a potential hazardous situation. For this reason, an in-depth characterisation and a multitechnique investigation of the landslide was performed, in order to evaluate its potential threat to the reservoir in the shortest possible time. Initially, a detailed geological study was conducted in order to define the structure and conditioning factors of the landslide, as well as to estimate its failure surface and volume. Subsequently, InSAR, GPR, and SfM methods were applied to obtain the historical displacement rates of the landslide. Therefore, our geological assessment will be useful to design future investigations with more precision, such as inclinometer and Differential Global Positioning System (DGPS) monitoring, topographic surveys, or exploration drilling in an optimal manner. At the same time, the remote sensing (i.e., InSAR and SfM) and geophysical (i.e., GPR) techniques provided displacement rates of the landslide before starting any ground monitoring action, not only in a quick and efficient approach, but also by using freely available or fast acquired data. Finally, all of the produced data were integrated to perform a preliminary hazard evaluation of the El Arrecife Landslide within the Rules Reservoir context.

\section{Case study}

The El Arrecife Landslide is an active translational landslide located within the western slope of the Rules Reservoir, in the Granada province (Southern Spain) (Fig.1). The El Arrecife Landslide is settled within the Permo-Triassic phyllites of the metamorphic Alpujárride Complex (Aldaya et al. 1979). The Alpujárride rocks underwent several deformational events that determined their geological complexity, which is manifested by multiple structures (i.e., foliations, lineations, folds and faults) visible both at small and large scale, as well as through different ages (e.g. Jabaloy et al. 1993; Simancas and Campos 1993; Azañón and Goffé 1997; Martínez-Martínez et al. 2002, 2004; Simancas 2018).

The Rules Reservoir area has been affected by several slope movements during the last decades, and is the subject of several landslide inventories (Fernández et al. 1997; Chacón et al. 2007). The most recent landslide inventory of the area was carried out by Reyes-Carmona et al. 2020a where the El Arrecife Landslide was mapped for the first time. The most noteworthy characteristic of the El Arrecife Landslide is that it does not show a prominent head scarp, or any other well-marked landslide morphology, which makes it not easily identifiable in the landscape (Reyes-Carmona et al. 2020a). These authors presented ground surface displacement data of the Rules Reservoir area, obtained my means of Differential Interferometric Synthetic Aperture Radar (DInSAR) techniques, which revealed the actual area of the sliding body (around $0.5 \mathrm{~km}^{2}$ ). Moreover, they estimated a mean surface velocity of up to $-25 \mathrm{~mm} / \mathrm{year}$ and an accumulated displacement of $10 \mathrm{~cm}$ in 3.5 years for the entire landslide body.

The activity of the El Arrecife Landslide has been also evidenced by the N-323 National Road, that runs across the landslide. This road has been consistently in need of repair work due to the existence of bumps, cracks and partial collapses of the road pavement (Fernández-Motril 2013). 
In 2013, the Spanish Ministry of Public Works and Transport invested a total of 3.8 million Euros to repair $8 \mathrm{~km}$ of the N-323 National Road, which entailed the resurfacing of the pavement and the structural restoration of the northern abutment of the El Arrecife Viaduct (Fernández-Motril 2013), located in the southern limit of the El Arrecife Landslide.

In addition, Reyes-Carmona et al. (2020a) pointed out the potential hazard of the landslide, considering a rapid acceleration and a catastrophic slope failure due to its translational character. According to the authors, the collapse of a slide mass into the reservoir would have devastating consequences not only for nearby populations, in case of a downstream flash flood, but also for some infrastructures like the N-323 National Road and some power lines.

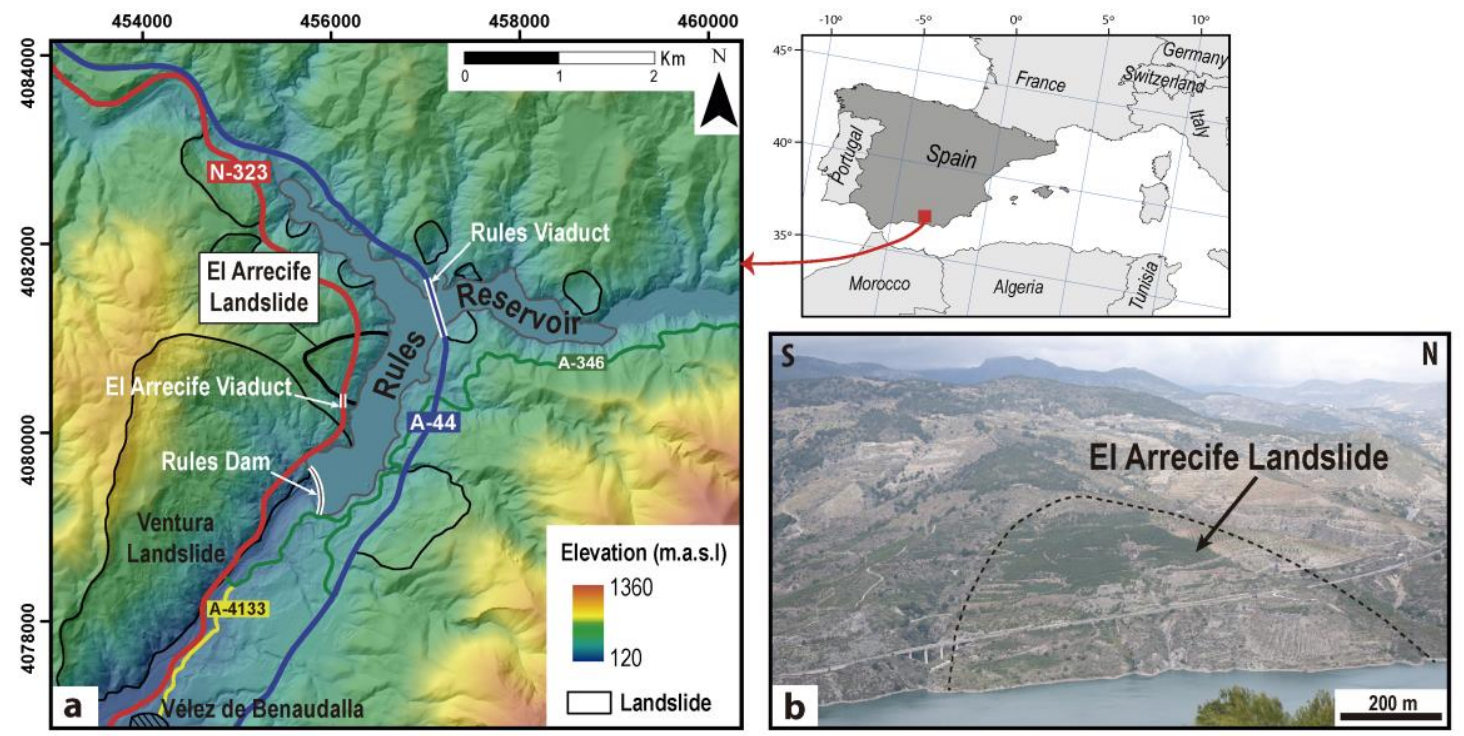

Fig. 1 a) Location of the El Arrecife Landslide in the Rules Reservoir, Southern Spain. The main roads (A-44, N-323, A-346 and A-4133) are marked, together with the critical infrastructures (Rules Viaduct and Rules Dam), and other relevant landslides in the surroundings of the reservoir. b) Panoramic view of the El Arrecife Landslide.

\section{Methodology}

Firstly, a detailed geological survey of the El Arrecife Landslide was performed, based on field observations. This step was essential to later estimate some important characteristics of the landslide, such as the surface of rupture and its volume. Subsequently, the recent displacement rate of the El Arrecife Landslide was calculated via a multi-technique approach. The techniques employed make use of already registered information, and provided quick results of variable precisions (mm/year to $\mathrm{dm} / \mathrm{year}$ ) at different time scales (5-20 years). This was a key information to evaluate the landslide activity during the last decades.

\subsection{Geological characterisation of the landslide and volume estimation}

The geological characterisation of the landslide was carried out through a structural study and a kinematic analysis of the slope, that led to the estimation of its volume.

\section{Structural study}

A detailed field survey, which included a structural analysis, was carried out both inside and outside of the El Arrecife Landslide perimeter. The most penetrative and visible structures in the study area are the $S_{2 A}$ foliation, which is usually the main foliation in the Permo-Triassic phyllites (Simancas 2018), and the $F_{3 A} \mathrm{~km}$-scale folds, widely distributed in the Alpujárride Complex, which fold the main foliation (Estévez et al. 1985; Simancas and Campos 1993). Therefore, both the $S_{2 A}$ and the $F_{3 A}$ have been identified as the geological structures that most influence the slope stability conditions of the El Arrecife area, for the purposes of this paper.

\section{Kinematic analysis}


A kinematic analysis, by means of stereographic projection methods, can be used to easily examine the direction in which a rock slope is more likely to slide (Wyllie and Mah 2004). The first step is to identify the main sets of discontinuities of the rock slope. In order to do so, field measurements were collected and grouped into main sets of discontinuities from 5 measurement stations (MS). These measurements were named MS- $0 n$, where $n$ is a number from 1 to 5 relating to each of the stations. Therefore, MS-02 and MS-03 are located within the EI Arrecife Landslide perimeter, while MS-01, MS-04 and MS-05 are located outside in surrounding area (Fig. 2). Our analysis was focused on measuring $S_{2 A}$ foliation planes. Then, the potential for these discontinuities to result in slope failures was evaluated by using the software DIPS, following the Planar Failure Analysis procedure (Rocscience 2004). This analysis consisted in: i) plotting the poles of the foliation planes, arranging them in different sets and obtaining a mean plane for each set; ii) plotting the average gradients of the El Arrecife Landslide slope, including the daylight envelope for each value; and iii) creating two friction cones, using the values of $20^{\circ}$ and $25^{\circ}$, which represent, respectively, the minimum and maximum internal friction angle of the involved rocks (i.e., phyllites) within the landslide (Wyllie and Mah 2004). The area of rupture is defined outside of the friction cone, where it intersects with the daylight envelope of the slope. Any poles, if plotted within the area of rupture, represent planes susceptible to planar sliding.

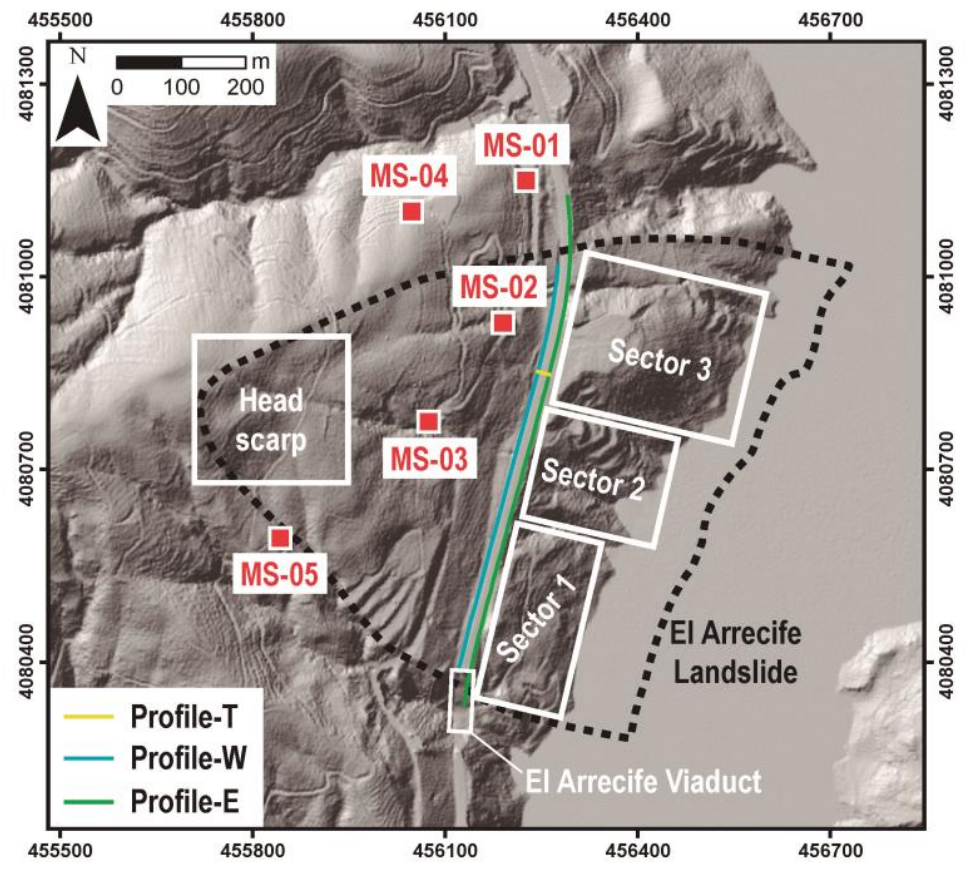

Fig. 2 Location of the 5 measurement stations (MS) for the kinematic analysis of the El Arrecife Landslide area and 3 profiles, acquired from the GPR survey: Profile "Transversal" (Profile-T), Profile "West" (Profile-W) and Profile "East" (Profile-E). The different areas (Head scarp, Sector 1 , Sector 2 and Sector 3) selected for the InSAR time series plots are also represented. This information is showed above a $2 \mathrm{~m}$ resolution hillshade model.

Moreover, the WEDGEFAIL tool from the SAGA (Automated Geoscientific Analyses) Geographic Information System (GIS) was used to identify the terrain elements where failure on geological discontinuities is kinematically possible through the frictional feasibility criteria (Günther et al. 2012 and references therein). A 5 m resolution Digital Elevation Model (DEM) was used to carry out four simulations of slope failure scenarios. For each simulation, a map that indicates areas of possible 'failure' or 'no failure' was obtained.

\section{Volume estimation}

The procedure to estimate the volume of the El Arrecife landslide initially consisted in generating a $2 \mathrm{~m}$ resolution Digital Elevation Model (DEM) of the landslide area before being anthropically modified by the reservoir construction. This was carried out by extracting the contours from a 1995 topographic map. Once the DEM was obtained, 6 longitudinal cross- 
sections were traced along a preferential direction of the landslide, and a possible surface of rupture was drawn within each cross-section, based on the kinematic analysis, the geometry of the slope, and its main morphological features (i.e., main scarp and toe). In this case, the preferential direction to trace the cross-section was the one parallel to the main dip direction of the foliation planes within the landslide perimeter. Afterwards, the contours corresponding to such failure surface were estimated in order to generate a DEM. By subtracting the landslide DEM from the failure surface DEM, a raster-type map that represented the thickness of the landslide body was obtained. The volume estimation was calculated by multiplying the average thickness value of the obtained map by the area of the landslide.

\subsection{Calculation of displacement rates of the landslide}

Three different techniques were applied to obtain mean annual displacement rates of the EI Arrecife Landslide during the last two decades: InSAR was useful to provide a short-term displacement rate of very slow movements $(\mathrm{cm}-\mathrm{mm} / \mathrm{yr})$, up to 5 years, while GPR and SfM techniques were used to estimate medium-term displacement rates of great magnitude (GPR > $\mathrm{cm} / \mathrm{yr}$; Photogrametry $>\mathrm{dm} /$ year), for the last 20 years. Moreover, InSAR supplied information about the temporal pattern of the recent displacement of the landslide by means of Time Series (TS).

\section{Synthetic Aperture Radar Interferometry (InSAR)}

The Parallel Small Baseline Subset (P-SBAS) processing service, available at the European Space Agency's Geohazards Exploitation Platform (GEP), was used to derive the InSAR data. Two different processing jobs were started, one in an ascending orbit and the other in a descending orbit. For the ascending orbit one, 101 Sentinel-1B images covering a period from the 30th of September 2016 to the 13th of March 2020 (3.5 years), and with a temporal sampling of 12 days, were used. For the descending orbit, 241 Sentinel-1A and Sentinel-1B images were used, which covered a period from the 22nd of December 2014 to the 19th of March 2020 (5 years), and had a temporal sampling of up to 6 days. For both processing jobs, the coherence threshold was set at 0.85 and the reference point was established in a small structure to the south of the Rules Reservoir (Lat 36.848, Long -3.497; WGS84 projection). The main outputs of each processing job were a set of points representing the annual mean velocity and the accumulated displacement at each image date. Both the velocity and the accumulated displacement were calculated along the satellite Line of Sight (LOS) direction.

To represent the mean velocity maps in both orbits, the stability range (i.e., the threshold for discriminating stable and unstable velocity points) was estimated as two times the standard deviation of the velocity of all the measured points (Barra et al. 2017). Therefore, the stability range was set between 6 and $-6 \mathrm{~mm} / \mathrm{year}$, for the ascending orbit processing job, and between 5 and $-5 \mathrm{~mm} / \mathrm{year}$ for the descending orbit job. The pixel size of the obtained points was $90 \mathrm{~m}$.

Then, the horizontal and vertical components of the mean velocity data were calculated. The procedure followed is the one described by Notti et al. 2014 and Béjar-Pizarro et al. 2017, which is applicable when both the ascending and the descending orbit data are available. Thus, assuming a small contribution of $\mathrm{N}-\mathrm{S}$ horizontal motion (Notti et al. 2014), the E-W horizontal ( $\left.V_{\text {eastward}}\right)$ and vertical $\left(\mathrm{V}_{\text {vertical }}\right)$ velocity components were calculated in a raster-type map with a resolution of $90 \mathrm{~m}$.

Lastly, the Time Series (TS) of accumulated displacement of the unstable points from the ascending orbit processing job was plotted, in order to define the temporal behaviour of the landslide movement and its relation to the reservoir water level variations, since, according to Reyes-Carmona et al. (2020a), such relationship is the main triggering factor of slope movement in the Rules Reservoir area. The unstable points were then assembled in different groups according to their distribution within the landslide (Fig. 2): i) the head scarp; ii) the N-323 National Road; iii) Sector-1, which corresponds to a smaller-size landslide within the lower part of the El Arrecife Landslide; iv) Sector-2, the central lower part of the landslide, and v) Sector-3, corresponding to the slag heap area. Then, an independent TS was plotted for each of the groups of points (median value). The reservoir water level measurements were obtained for free 
from the public Andalusian Automatic System of Hydrologic Information (S.A.I.H. HIDROSUR, www.redhidrosurmedioambiente.es).

\section{Ground Penetrating Radar (GPR)}

A RAMAC Ground Penetrating Radar system (Mala Geosciences) with a $400 \mathrm{MHz}$ antenna was used to acquire three radar profiles (Fig. 2): two of them along the N-323 National Road (i.e., Profile "East" and Profile "West") and the other one across the road (Profile "Transversal"). The Profile "West" is $647.94 \mathrm{~m}$ long and runs the western side of the road while the Profile "East" is $820.96 \mathrm{~m}$ long and runs the eastern side of the road (Fig. 2). The reference point $(0 \mathrm{~m})$ on the profiles was established in the northern abutment of the El Arrecife Viaduct (Fig. 2). The Profile "Transversal" was acquired transversely to the road and has a length of $13.42 \mathrm{~m}$ (Fig. 2). The radar signal could penetrate at a depth of $2 \mathrm{~m}$ underground, providing a profile resolution of 10 $\mathrm{cm}$. The data were recorded with a sampling interval of $5 \mathrm{~cm}$ and a total time window of $55 \mathrm{~ns}$. By means of reflected wave methods (see Conyers 2013 for further descriptions), a terrain velocity of $9.6 \mathrm{~cm} / \mathrm{ns}$ was calculated. The raw data were processed by using the GSSI RADAN 7 software (GSSI 2012). The processing chain of the raw data consisted of six steps: i) adjusting to time zero, in this case, set at $3.9 \mathrm{~ns}$; ii) elimination of the air-ground contact; iii) application of a gain filter to reduce the intensity on the signal; iv) migration of the data to eliminate diffraction effects; v) deconvolution to increase the vertical resolution, as well as cleaning the signal; and vi) application of a vertical filter, in this case between 250 and 750 $\mathrm{MHz}$, to remove background noise.

Since the El Arrecife Landside activity has caused a considerable damage (i.e., cracks, potholes, sinking) along the N-323 National Road, multiple repairs of the road pavement have been carried out during recent years (State Road Demarcation 2020, pers. comm.) and, thus, a sequence of asphalt layers can be detected by the GPR. Such layers are well-evidenced by continuous and almost horizontal reflectors along the profiles. The temporal evolution of this layering can be used to infer the vertical displacement rate along the road (Lissak et al. 2015). The latter can then be used to extrapolate the displacement rate of the landslide. Thus, the displacement rate can be estimated by dividing the thickness of the whole sequence of asphalt layers by the total period of time of the road paving.

\section{Structure-from-Motion (Sfm)}

The methodology described by Riquelme et al. (2019) was applied to detect ground movements in the Rules Reservoir from its construction (2004) to present time. For this purpose, two different surfaces from the years 2000 and 2014 were compared. The 2014 DEM was generated by using Airborne Laser Scanner (ALS) data, freely obtained from the PNOA project (https://pnoa.ign.es/). The 2000 DEM was generated by exploiting aerial photos and using the SfM technique. To apply this technique, it was necessary to insert Ground Control Points (GCP) into the photos. For each photo, several distinctive features were identified in the 2014 DEM (ALS-DEM). The coordinates of those points were extracted to generate the 2000 DEM dense cloud, which was then finally compared with the ALS-DEM.

\section{Results}

\subsection{Geological structure of the El Arrecife Landslide}

The Alpujárride Complex phyllites are the predominant lithology within the El Arrecife Landslide area, whose boundary is indicated by a small-spaced dashed line (Fig. 3). Within the landslide perimeter, phyllites outcrops appear considerably fractured and partially covered by debris or soil and colluvium deposits (Fig. 4a). By contrast, outcrops are better-preserved outside of the landslide perimeter, and phyllites show a noteworthy level of tectonisation (Fig. 4b). The most recognisable tectonic fabric of the Alpujárride phyllites is the $S_{2 A}$ foliation with NE-SW to E-W trend, dipping SE (Fig. 3). A less prevalent NW dipping NE-SW trend is also present. Both foliation trends evidence the existence of centimetre to metre scale minor folds (Fig. 4b), with fold axes plunging at around $20^{\circ}$ to $245^{\circ}$ approximately, (see stereographic projection in Fig. 3) and showing a NW vergence. These minor folds are associated with the existence of a major fold, interpreted as a $F_{3 A}$ fold. The cross-section in Fig. 3 illustrates this foliation pattern, mainly 
dipping towards SE, while the NW dipping trend forms the short limbs of $F_{3 A}$ minor folds. The surface of rupture of the El Arrecife Landslide was drawn according to the plane 21/120 (dip/dip direction).

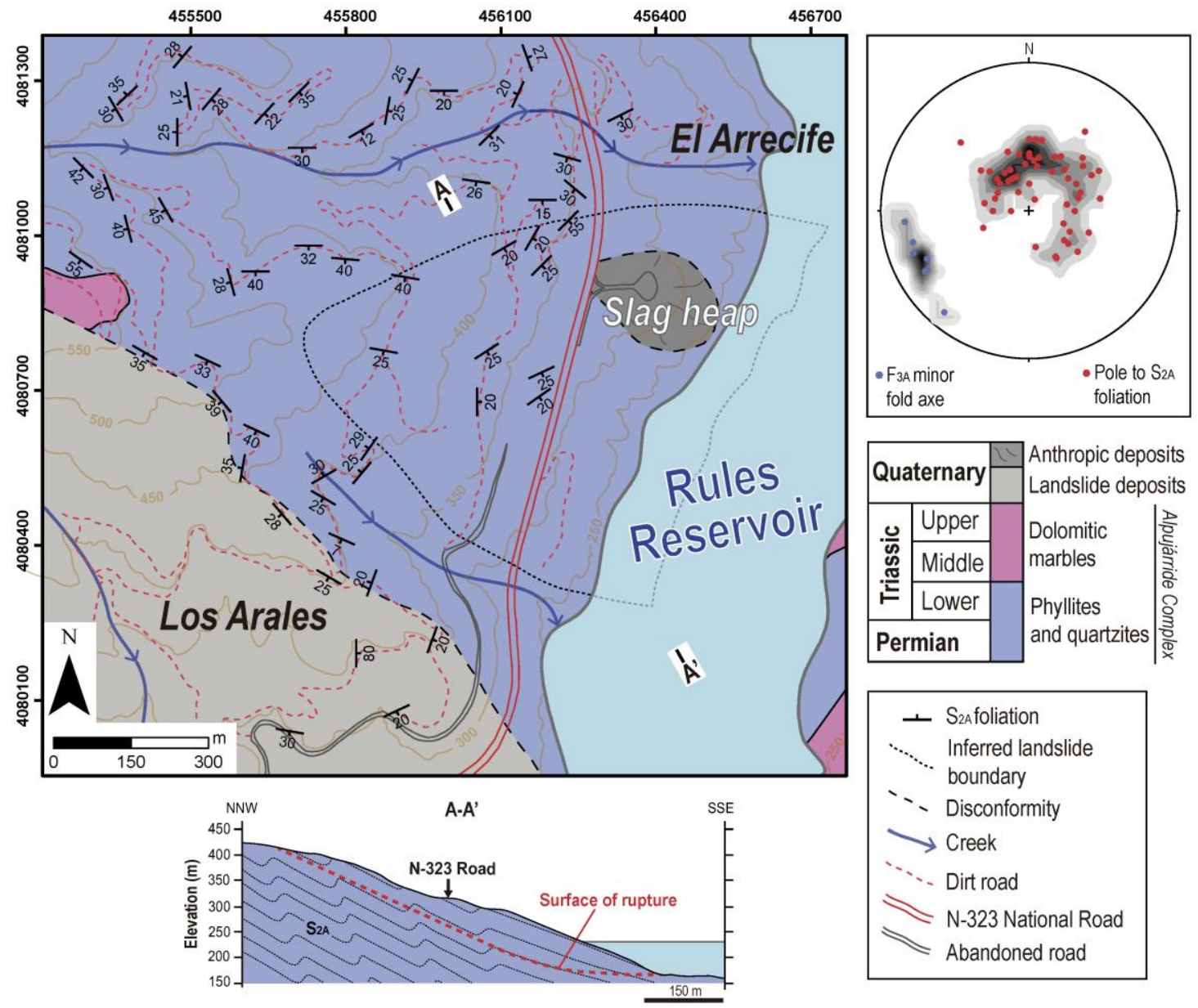

Fig. 3 Geological map and cross-section of the El Arrecife Landslide area. Poles to $S_{2 A}$ foliation and $F_{3 A}$ minor fold axes are plotted in stereographic projection (lower hemisphere, equal area).
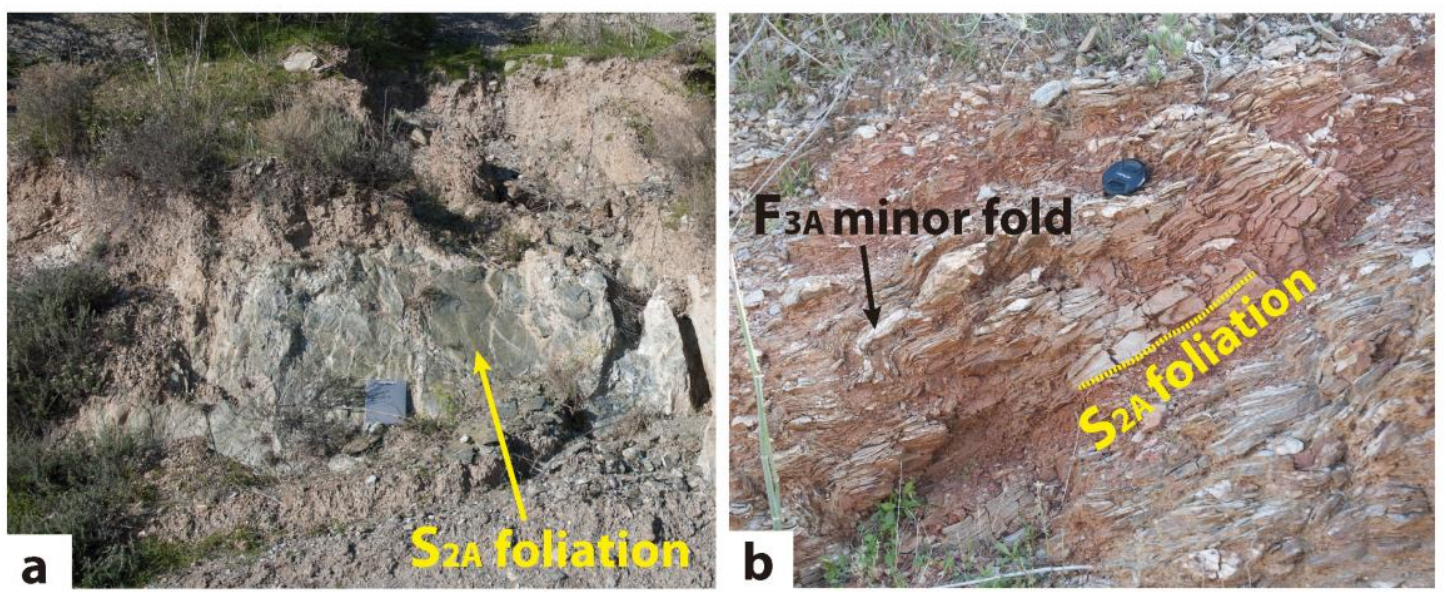

Fig. 4 Field photos of the Alpujárride phyllites in the El Arrecife Landslide area. a) An outcrop showing the main foliation $S_{2 A}$ almost covered by colluvial deposits within the landslide perimeter. b) An outcrop covered by red-coloured soil deposits located out of the landslide perimeter, where $\mathrm{F}_{3 \mathrm{~A}}$ minor folds and the $\mathrm{S}_{2 \mathrm{~A}}$ foliation can be observed. 
Such assumption would imply an oblique (towards $\mathrm{N}^{2} 2^{\circ} \mathrm{E}$ ) movement of the landslide body with respect to the maximum gradient direction of the slope (Fig. 5a). Despite the fact that the whole mass may be sliding downhill through a planar surface of rupture (i.e., translational landslide), the lower part of the landslide is affected by smaller-sized rotational movements, evidenced by several secondary scarps (Fig. 5a). These movements are progressively eroding the El Arrecife Landslide foot, clearly influenced by the reservoir water level fluctuations. Moreover, above the N-323 National Road active piping phenomena were identified (Fig. 5b), along with several opened cracks with vertical steps up to $0.5 \mathrm{~m}$ (Fig. $5 \mathrm{c}$ ). These findings are clear signals of the El Arrecife Landslide's activity.
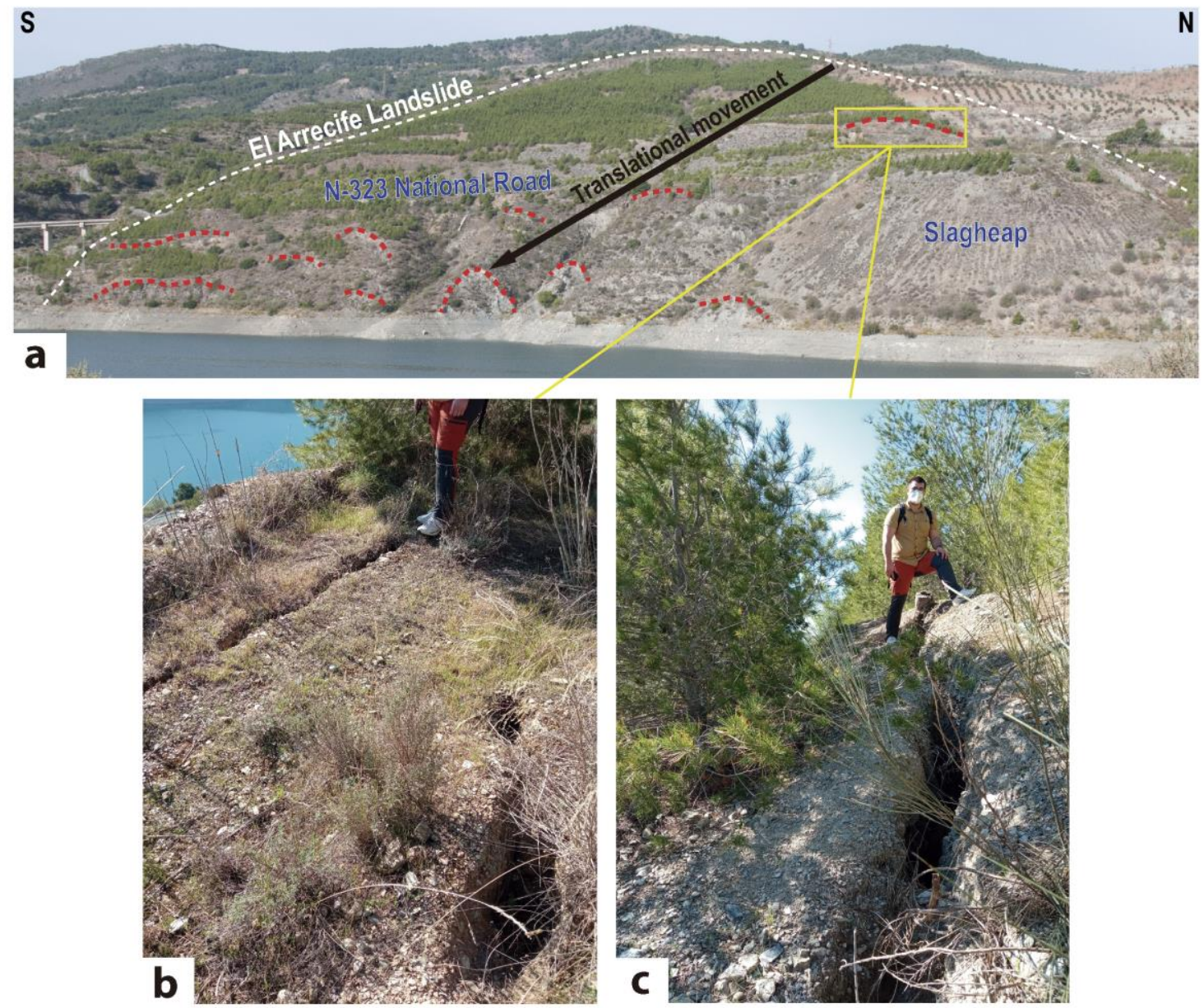

Fig. 5 a) Panoramic view of the El Arrecife Landslide. Rotational secondary scarps are indicated by a red-coloured dashed line. The translational direction of movement is also indicated by a black arrow. b) Photograph of the piping phenomena within the El Arrecife Landslide perimeter. c) Photograph of a crack with a superficial vertical step of $0.5 \mathrm{~m}$ and $1.5 \mathrm{~m}$ depth in the El Arrecife Landslide perimeter.

\subsection{Kinematic analysis of the El Arrecife Landslide area}

The kinematic analysis is shown in two different stereographic projections, relative to inside and outside of the El Arrecife Landslide perimeter. For both cases, the area of rupture is defined by the intersection of the daylight envelope of the slope with the $20^{\circ}$ friction cone (Fig. 6). In a first approach, 3 foliation trends are clearly noticed: i) a NE-SW trend, corresponding to the measurement stations within the landslide (i.e., MS-02 and MS-03); ii) a E-W trend, corresponding to stations located outside of the landslide and close to its northern limit (i.e., MS-01 and MS-04), and iii) a NW-SE trend, corresponding to MS-05, located outside of the landslide perimeter and close to its southern limit (Fig. 2). Within the landslide, almost all of the poles can be assembled in one set (Set-1), which is defined by the mean plane 34/140 (dip/dip direction). Only one of these poles is plotted within the area of rupture, which corresponds to the 
plane 21/120 (dip/dip direction), being the most likely surface to generate the planar failure along the El Arrecife slope. This pole and its related plane were named 'critical pole' and 'critical plane', respectively. Outside of the landslide perimeter, the distribution of poles is clearly arranged into two groups of poles, named Set-2 and Set-3, that are defined by the mean planes of $30 / 188$ and $28 / 306$, respectively. None of these poles are plotted within or near the area of rupture.

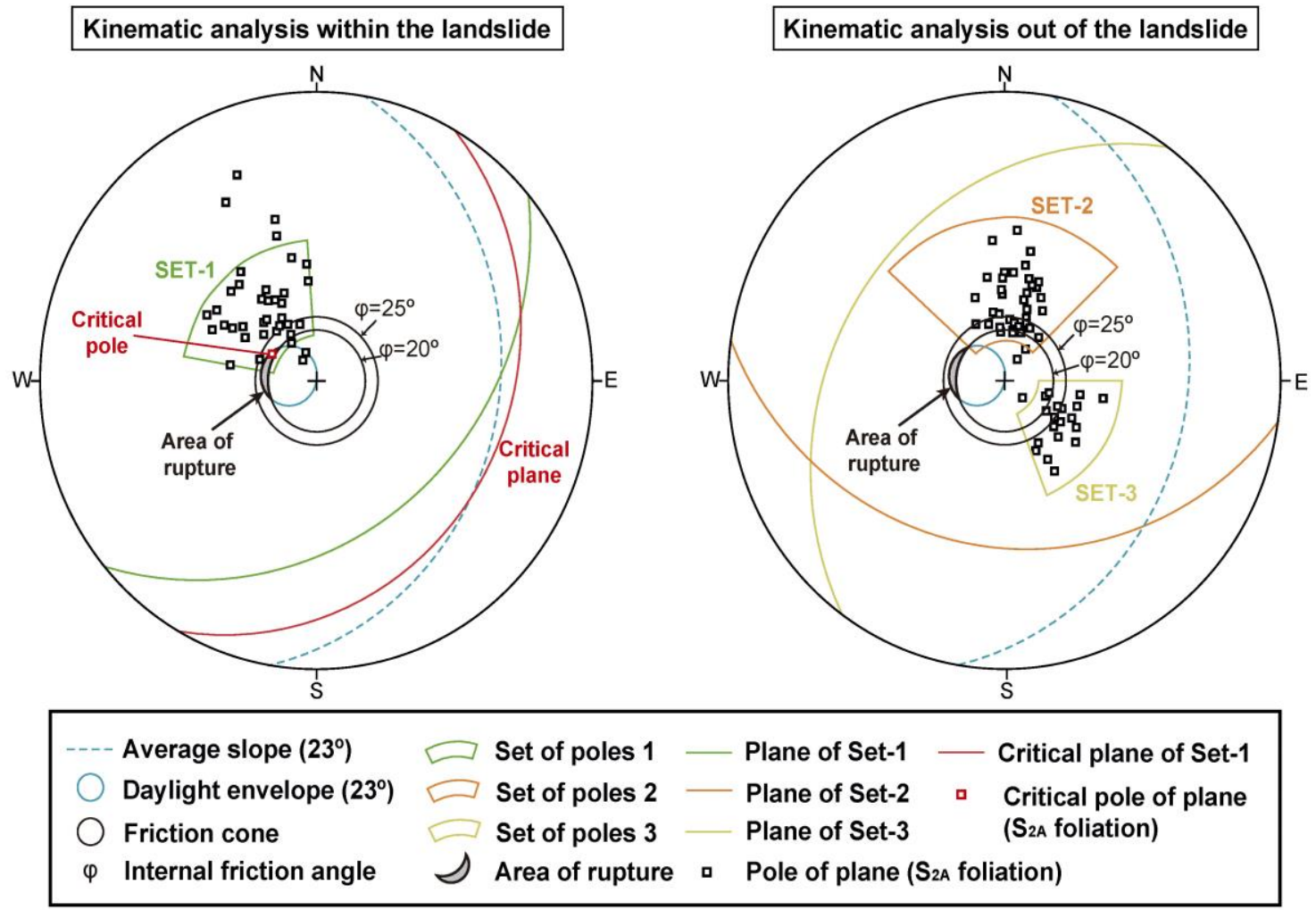

Fig.6 Kinematic analysis of the El Arrecife Landslide, inside and outside of the landslide perimeter. The main discontinuity sets of the area and their mean planes are shown.

The previous statements are also confirmed by the analysis done by means of SAGA-GIS (Fig. 7). The 'critical plane' of Set-1 defines an extensive area where failure is likely to occur, especially within the El Arrecife Landslide area. This is not the case for Sets-1, Set-2 and Set-3, as almost any slope failure areas are estimated within the landslide perimeter. These results led us to confirm that planes with orientations close to $21 / 120$ (dip/dip direction) can potentially generate slope failures in the area, and thus it is reasonable to assume such plane as the possible surface of rupture of the El Arrecife Landslide.
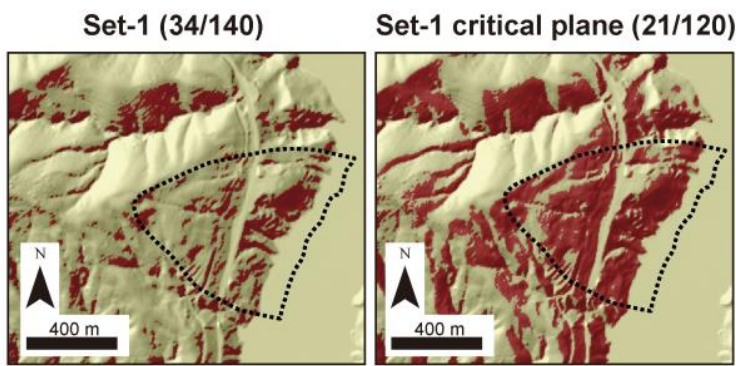

Set-2 (30/188)

Set-3 (28/306)
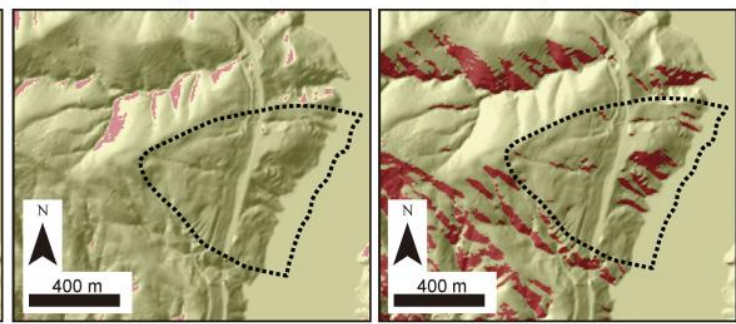

$\cdots .$. El Arrecife Landslide

Failure

No failure

Fig. 7 Areas where slope failure is kinematically possible through each of the main discontinuity sets of the El Arrecife Landslide area.

\subsection{Volume of the El Arrecife Landslide}


Assuming the 'critical plane' as the surface of rupture, 6 longitudinal cross-sections were traced across the landslide according to the 'critical plane' dip direction $\left(\mathrm{N} 120^{\circ} \mathrm{E}\right)$. In the same way, the surface of rupture was established as a flat plane dipping $21^{\circ}$ (dip of the 'critical plane') for each cross-section. The resultant map of the landslide body thickness of the El Arrecife Landslide is shown in Fig. 8. The maximum thickness is $72.6 \mathrm{~m}$, estimated in the lower southern part of the landslide. Thickness values near to $0 \mathrm{~m}$ clearly define the head scarp, especially along the northern edge of the landslide and in contrast to the southern limit. Knowing that the mean thickness value of the landslide body is $31.1 \mathrm{~m}$, and that the landslide area is $473107 \mathrm{~m}^{2}$, a volume of 14.7 million $\mathrm{m}^{3}$ was estimated. According to Fell's (1994) classification, this one can be considered as an 'extremely large' landslide.

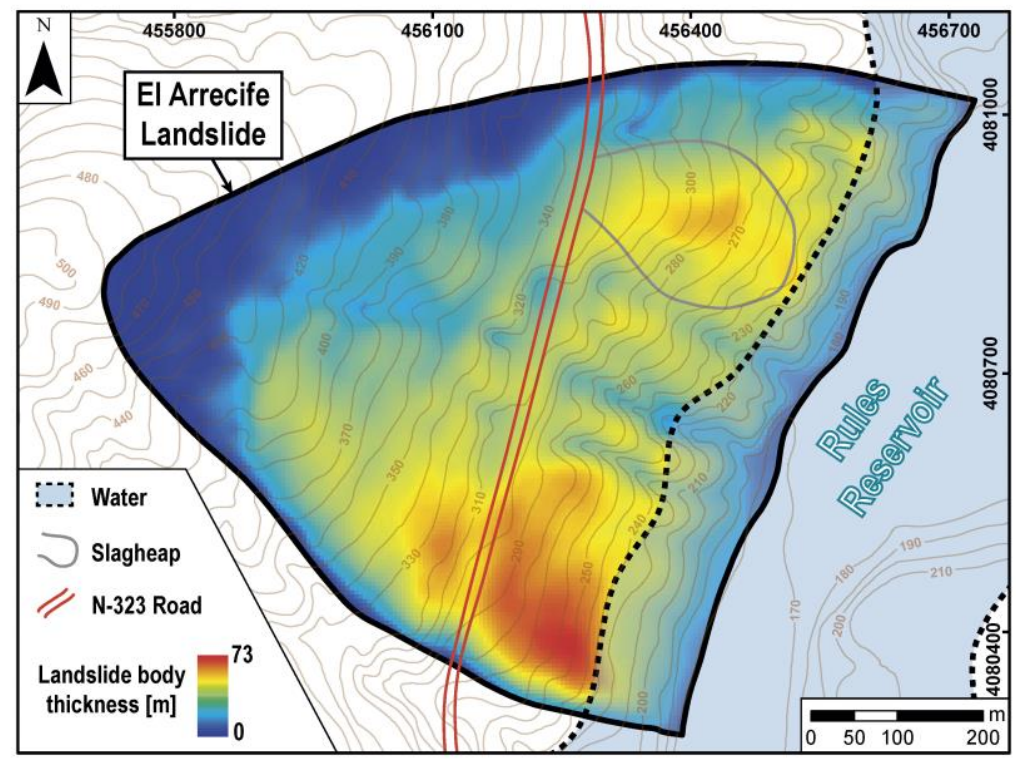

Fig. 8 Map of the thickness of the El Arrecife Landslide.

\subsection{InSAR results}

\section{Velocity maps}

Unstable points were detected in both ascending and descending geometries within the El Arrecife Landslide perimeter, mostly in the lower part of the slope (Fig. 9). Since the velocity was estimated along the satellite Line of Sight (LoS) direction, negative values indicate that points move away from the satellite, while positive values refer to points moving towards the satellite. For the ascending processing, negative values indicate an eastward movement along the El Arrecife Landslide slope, in addition to subsidence in flat areas. On the contrary, for the descending processing, the eastward movement of the landslide is indicated by positive values. The point coverage is higher in the ascending processing, from which unstable points showing a displacement of up to $31 \mathrm{~mm} / \mathrm{yr}$, in the southern lower part of the landslide, were obtained (Fig. 9). This area corresponds to a small-size landside, mapped by Fernández et al. (1997) and Chacón et al. (2007), and its activity was confirmed by the InSAR data presented in ReyesCarmona et al. (2020). Along the N-323 National Road, displacement rates fluctuate around 20 $\mathrm{mm} / \mathrm{yr}$, with the highest rate obtained in the slag heap area, showing a value of $39 \mathrm{~mm} / \mathrm{yr}$. By contrast, the descending processing shows a worse quality of point coverage, but the displacement value of the lower part of the El Arrecife Landslide, including the N-323 National Road, can be confirmed (Fig. 9). 

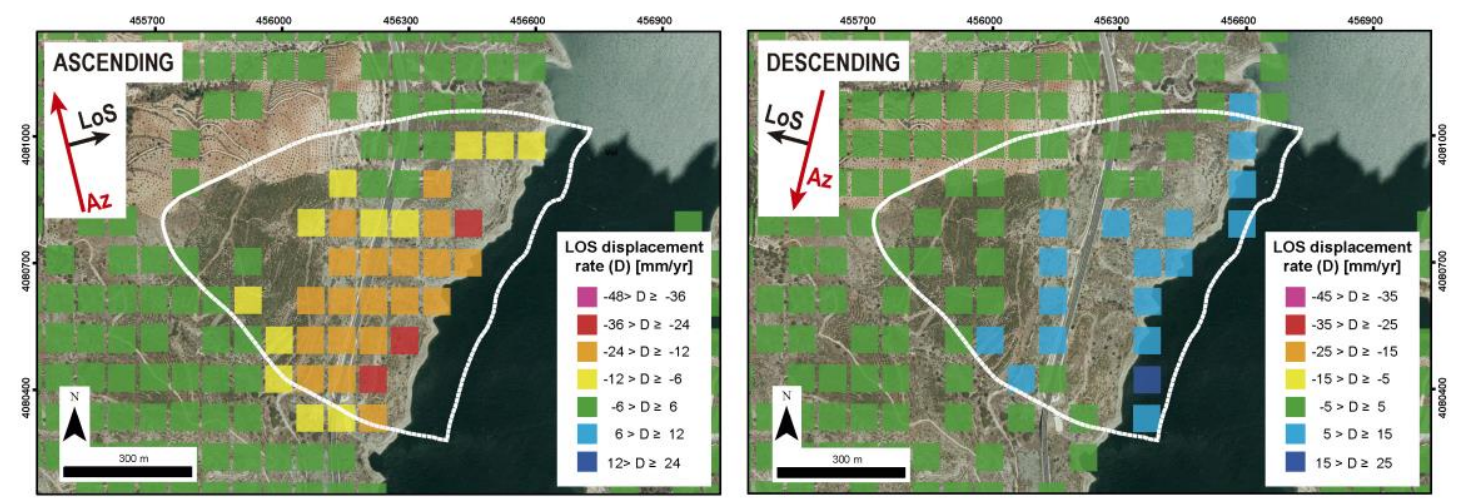

Fig. 9 Surface velocity maps in ascending and descending geometries of the El Arrecife Landslide area. Red arrows indicate satellite azimuth $(\mathrm{Az})$ and black arrows indicate the Line of Sight (LoS) direction.

Fig. 10 shows eastward and vertical components of the surface displacement data, obtained by the ascending and descending orbits P-SBAS processing. Positive and negative values indicate eastward and downward movement, respectively. Eastward displacement reaches values of 4.5 $\mathrm{cm} / \mathrm{yr}$ along the lower part of the landslide, which is consistent with a mass movement downhill of the slope. Negative vertical displacement (subsidence) is registered almost in the entire landslide area, except from the head scarp. Thus, the mean vertical velocity is around -1.5 $\mathrm{cm} / \mathrm{yr}$ while the highest value $(-2 \mathrm{~cm} / \mathrm{yr})$ is registered within the slag heap area.
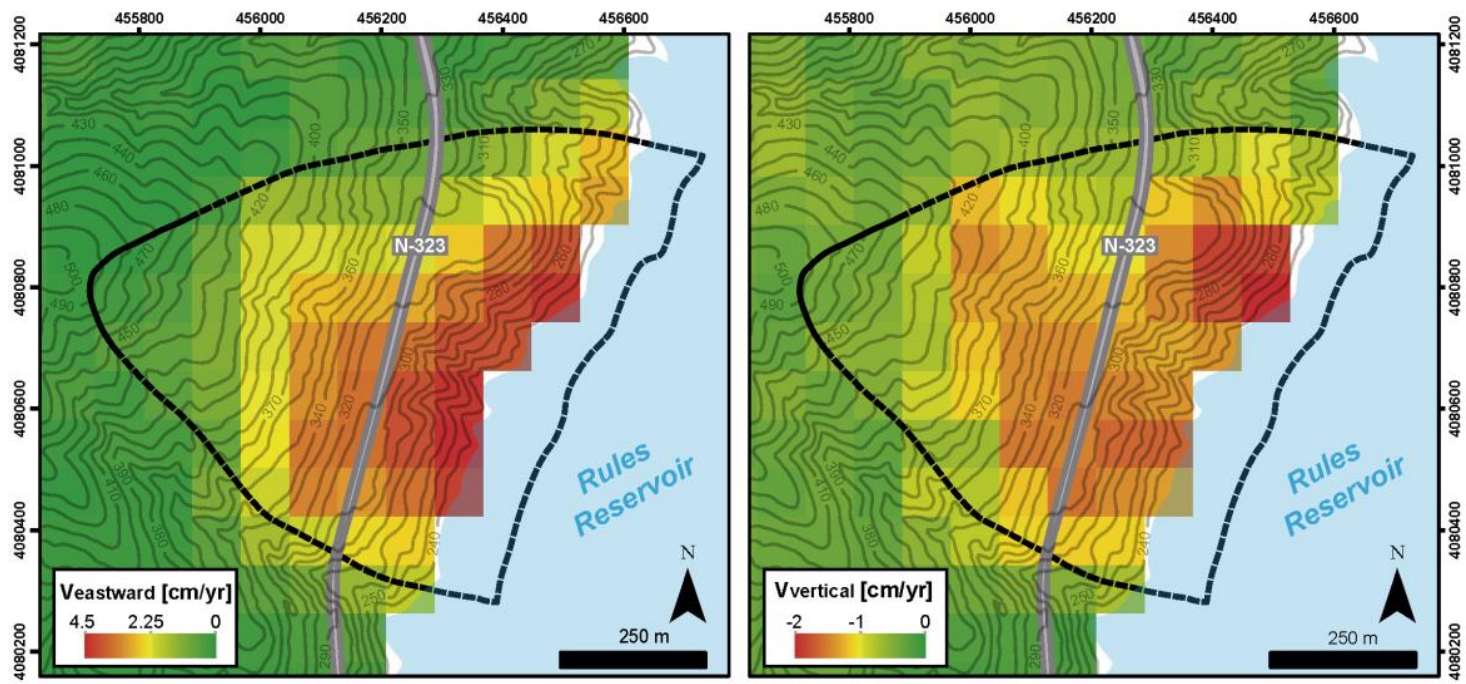

Fig. 10 Surface displacement velocity in the eastward and vertical direction in the El Arrecife Landslide. The landslide boundary is marked by a black line.

\section{Analysis of the time series of accumulated displacement}

Fig. 11 shows the Time Series (TS) of the 5 groups of points within the El Arrecife Landslide area together with the Rules Reservoir water level variations. The TSs of the head scarp and the N-323 National Road, as well as the mean TS of all the points within the landslide perimeter, are plotted in Fig. 11a, while the TS of Sectors 1,2 and 3 are plotted in Fig. 11b. Such distinction refers to the difference in the TSs displacement patterns: almost linear in the El Arrecife Landslide, its head scarp and the N-323 Road (Fig. 11a), as opposed to the steeped trend of Sectors 1, 2 and 3 TSs (Fig. 11b). The steeped trend of Sectors 1, 2 and 3 is evidenced by two acceleration periods (i.e., change to a steeper slope of the line trend) that fits well with two periods of reservoir water level decline: i) during the second d, from autumn 2017 to spring 2018, and ii) during the third decline, from summer 2019 to autumn 2019 (Fig. 11b). These 
acceleration periods are not observable in the main scarp TS, which does not show a significant displacement, in the El Arrecife Landslide, or in the N-323 National Road TSs.
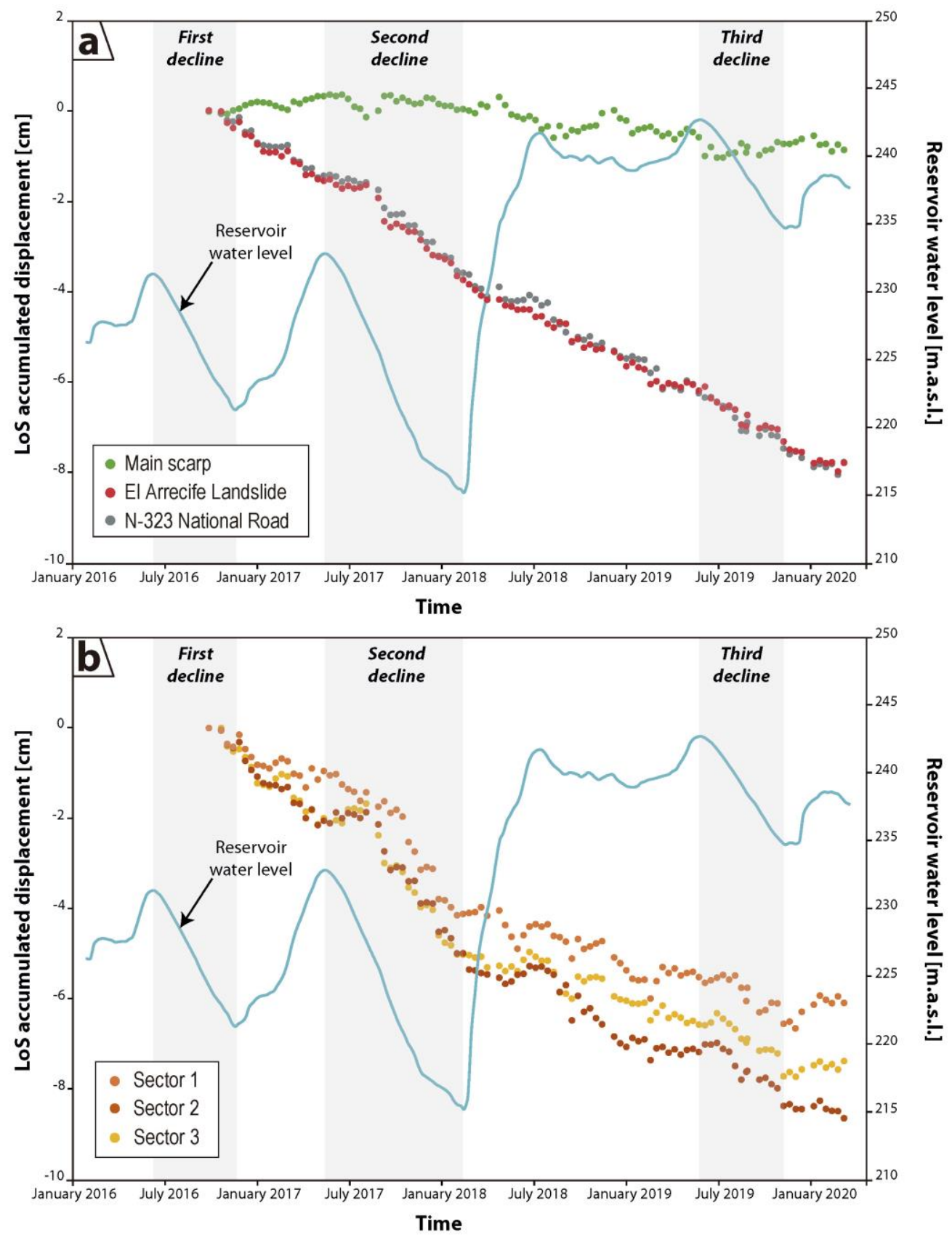

Fig. 11 Time Series (TS) in Line of Sight (LoS) direction of accumulated displacement of (a) the El Arrecife Landslide, the landslide main scarp and the N-323 National Road and (b) TSs of the Sectors 1, 2 and 3. The related sectors for each TS are indicated in Fig. 2. Water level variations of the Rules Reservoir is also plotted as a blue-coloured line. Grey columns indicate three periods of decrease of the reservoir water level, from March 2015 to March 2020.

\subsection{Estimated medium-term displacement rates}

\section{SfM}

The difference between the two DEMs obtained (Fig. $12 \mathrm{a}, \mathrm{b}$ ) within the Rules Reservoir area is shown in Fig. 12c. A zoom view of the slag heap area and its estimated elevation change is also presented for a better appreciation (Fig. 12d, e, f). Negative values are indicated in red and correspond to subsiding areas, while green colours correspond to stable areas. In order to 
quantify the difference between the DEMs, taking into account the error of this technique, a histogram that shows the distribution of the elevation changes was produced, where two Gaussian distributions seem to be present (Fig. 12g). The two Gaussian distributions were fitted, and the R-Squared value obtained was 0.993 , showing a good fit. The mean $(\mu)$ of the first distribution (Dist ${ }_{1}$ ) is $-4.27 \mathrm{~m}$, which is approximately close to the technique error, according to Riquelme et al. (2019). However, the centre of the second distribution (Dist2) is located at $7.94 \mathrm{~m}$. These values correspond to those located within the slag heap area. As the difference in time between both models is $14 \mathrm{yr}$, an annual subsidence rate of up to $26 \mathrm{~cm} / \mathrm{yr}$ was estimated within the slag heap area.

No other changes of enough magnitude to be detected by this technique ( $>5 \mathrm{~m}$ ) have been recorded in the area. Therefore, the movements represented by several scarps, observed within the foot of the El Arrecife Landslide, could not be dated. What is clear is that, apart from the subsidence in the slag heap area, no rapid movement occurred during the analysed period (2000-2014).

a) $3 \mathrm{DPC}(\mathrm{SfM})$ August 2000

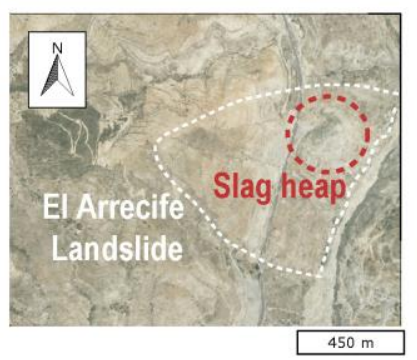

d) Slag heap view December 2014

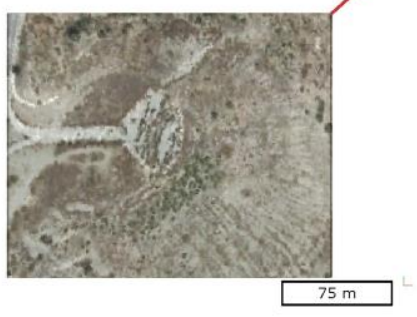

b) 3DPC (ALS)

December 2014

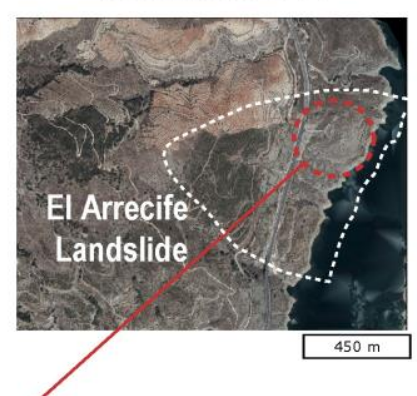

e) Slag heap: vertical change over 3DPC

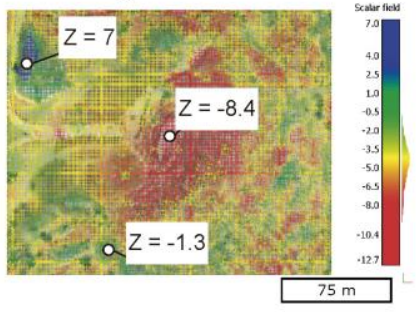

c) Raster vertical change [m]

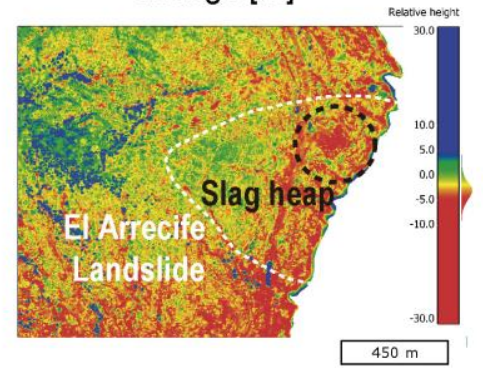

f) Slag heap: vertical change [m]

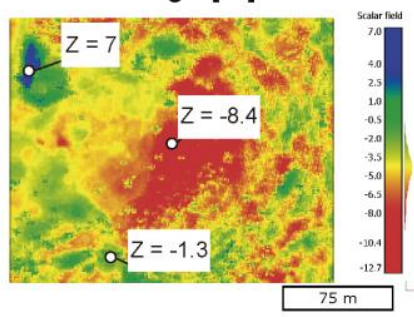

g) Histogram of vertical changes: fitting to two gaussian curves

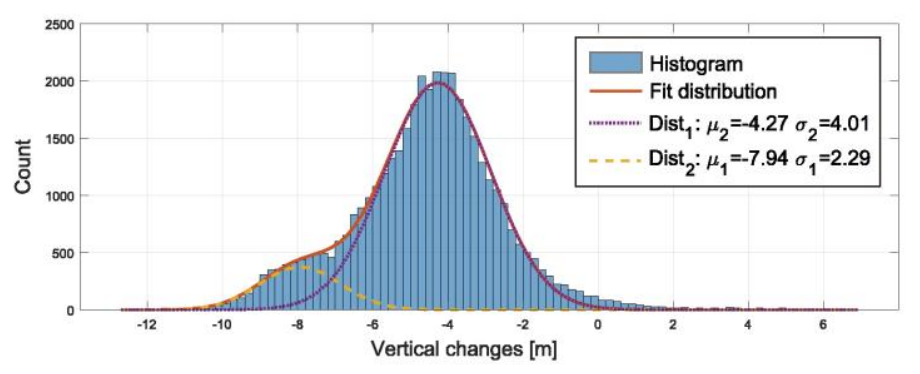

Fig. 12 Results from the Structure-from-Motion (SmF) technique within the Rules Reservoir. a) 3-Dimention Points Cloud (3DPC) obtained from SmF procedure using aerial photos from August 2000. b) 3DPC obtained from the Airborne Laser Scanner (ALS) data from December 2014. c) Vertical change in metres, calculated from the comparison of the 2000 and 2014 models. d) Zoom view of the slag heap area, from the December 2014 3DPC. e) Vertical change in metres of the slag heap area, shown over the 2014 3DPC. f) Vertical change in metres of the slag heap area. g) Histogram of the elevation changes distributions. Notice the two different gaussian distributions Dist ${ }_{1}$ and Dist2. 


\section{GPR}

The GPR Profiles "East" and "West" are shown in Fig.1 (Supplementary Material) together with a top view scheme of the N-323 National Road damages, based on field observations. Fig. 13 show the same top view scheme (Fig. 13d) and a few field photographs of the main damaged areas found along the road (Fig. 13a, b, f, g), as well as two extracts from the Profile "East" (from 0 to $115 \mathrm{~m}$ ) (Fig. 13c) and the Profile "West" (from 390 to $515 \mathrm{~m}$ ) (Fig. 13e). In both GPR profiles, several asphalt layers were identified. These have been progressively superimposed since the construction of the N-323 road, in 1997, until the acquisition date of the profiles in March 2020. The minimum thickness of the asphalt layers sequence within the landslide body is around $0.7 \mathrm{~m}$ in both profiles, while the maximum thickness is up to $1 \mathrm{~m}$ in the Profile "West", and up to $1.2 \mathrm{~m}$ in the Profile "East". Such increase in thickness towards to east of the road is coherent with the El Arrecife Landslide's downhill movement. The minimum thickness of the asphalt layering outside of the landslide perimeter is also around $0.7 \mathrm{~m}$ (Fig.14a). Therefore, there is an extra asphalt thickness of up to $0.3 \mathrm{~m}$ and $0.5 \mathrm{~m}$ in the Profile "West" and "East", respectively, as a result of the additional resurfacing work done on the road across the landslide. Knowing that the last layer of asphalt was settled in 2019 and the total registered time in GPR profiles is 22 years, a mean annual subsidence rate of the road from $1.4 \mathrm{~cm} / \mathrm{yr}$ to 2.3 $\mathrm{cm} / \mathrm{yr}$ was estimated.

a) Northern abutment

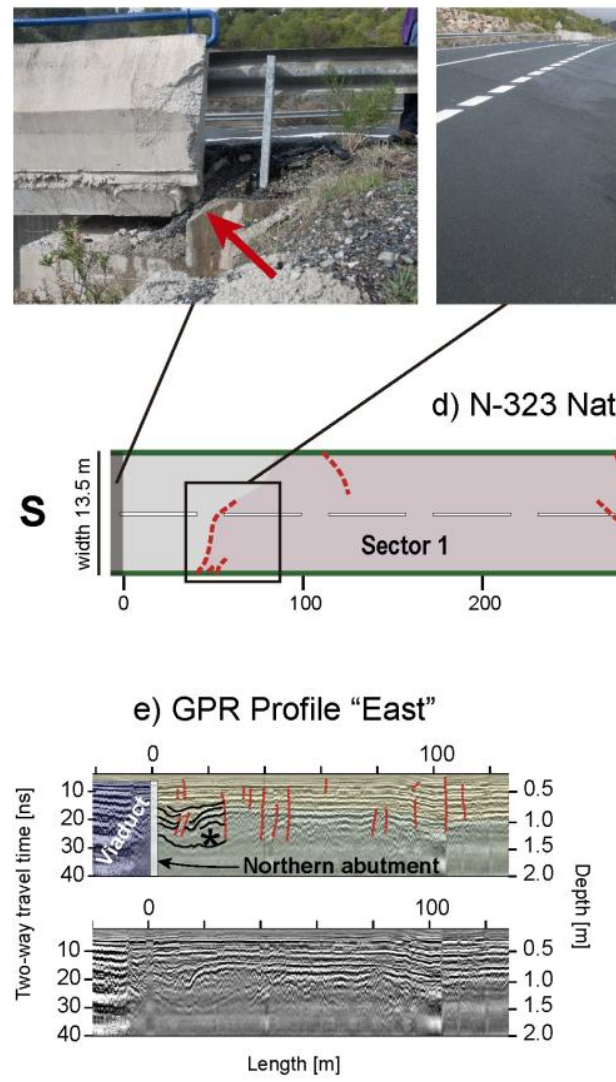

b) Cracks

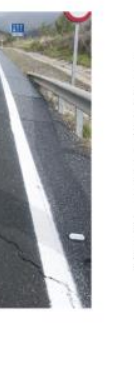

c) GPR Profile "West"

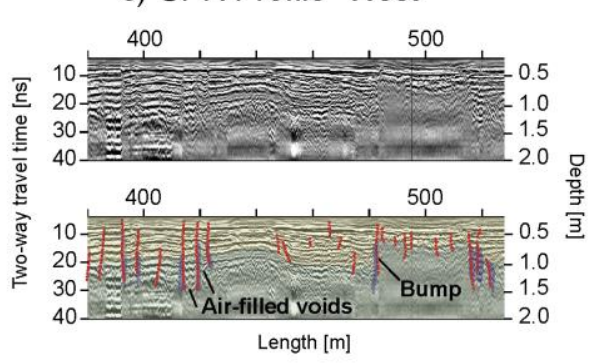

al Road top view scheme
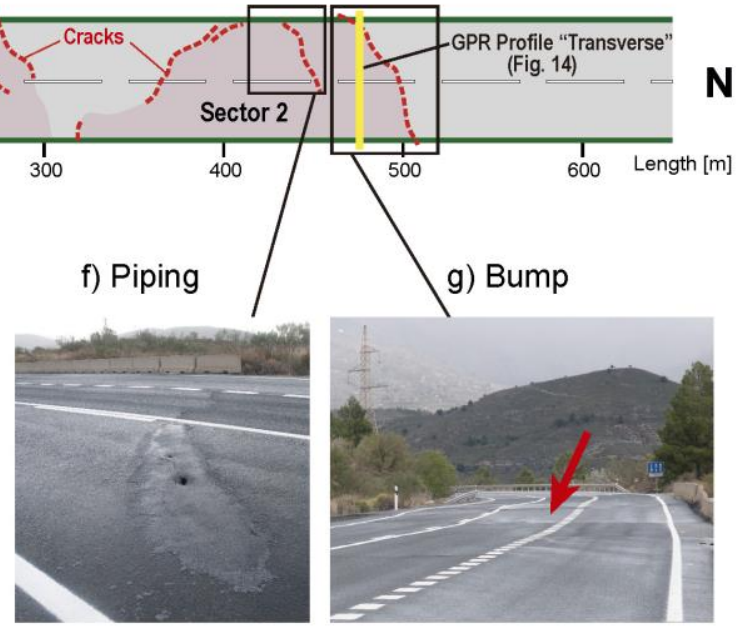

Asphalt layers

Slide mass

Air $\quad \cdots+\cdots$, Cracks

$\longrightarrow$ Bedrock bedding

* Folded layers associated with abutment deformation

Fig. 13 a) Photograph of the northern abutment of the El Arrecife Viaduct. Notice the broken corner marked with a red arrow. b) Cracks on the N-323 National Road surface. c) Extract of the GPR Profile "West" (length from 390 to $515 \mathrm{~m}$ ). d) Top view scheme of the N-323 National Road that shows the main damaged areas observed. e) Extract of the GPR Profiles "East" (length 
from 0 to $115 \mathrm{~m}$ ). f) Photograph of a crack with associated piping phenomena. g) Bump on the N-323 National Road, marked with a red arrow.

A large number of vertical cracks were identified within both GPR profiles, which are evidenced by cuts in the continuity of the reflectors (Fig. 13c, e). Associated to some of these cracks, several "air-filled voids" were identified, which are related to opened tensional cracks as a result of piping phenomena. The majority of these cracks do not affect the most superficial asphalt layers and just a few of them are visible on the N-323 National Road surface (Fig. 13a, b, f, g). Along the road, several cracks that delimited two sectors, (Sectors 1 and 2), were mapped, and found to be affected by smaller-scale rotational slides within the whole landslide body (Fig. 13d). Close to Sector 1, some damage can be observed within the northern abutment of the El Arrecife Viaduct (Fig. 13a), attributed to the pushing of the viaduct into the abutment, which required repair works in 2014 (State Road Demarcation 2020, pers. comm.). Folded bedding and asphalt layers can be appreciated within the Profile "East" (Fig. 13e), probably associated with the abutment deformation. Moreover, several NW-SE incipient cracks were found at the southern boundary of the Sector 1 (Fig. 13b). Within Sector 2, a NE-SW crack with associated piping was found (Fig. 13f), as well as a prominent NE-SW bump (Fig. 13g) that defines the northern boundary of this sector. All of these findings are indicators of the El Arrecife Landslide recent activity, at least during the last two decades. Moreover, a possible northern boundary of the El Arrecife Landslide can be inferred at $625 \mathrm{~m}$ within the Profile "East" (Fig. 14a). Such limit clearly separates the slide mass, which is characterised by the absence of reflectors along the profile, from the in-situ bedrock that shows a well-marked bedding from 625 to $730 \mathrm{~m}$.

Additionally, the Profile "Transverse" (Fig. 14b) reveals other morphologies typically related to landslide activity. The asphalt layers define a cumulative wedge-out, that is the result of a progressive rotational movement (Gutiérrez et al. 2010) and subsequent deformation of the road. This finding clearly indicates a rotational kinematic for the lower part of the El Arrecife Landslide.

a) Profile "East"
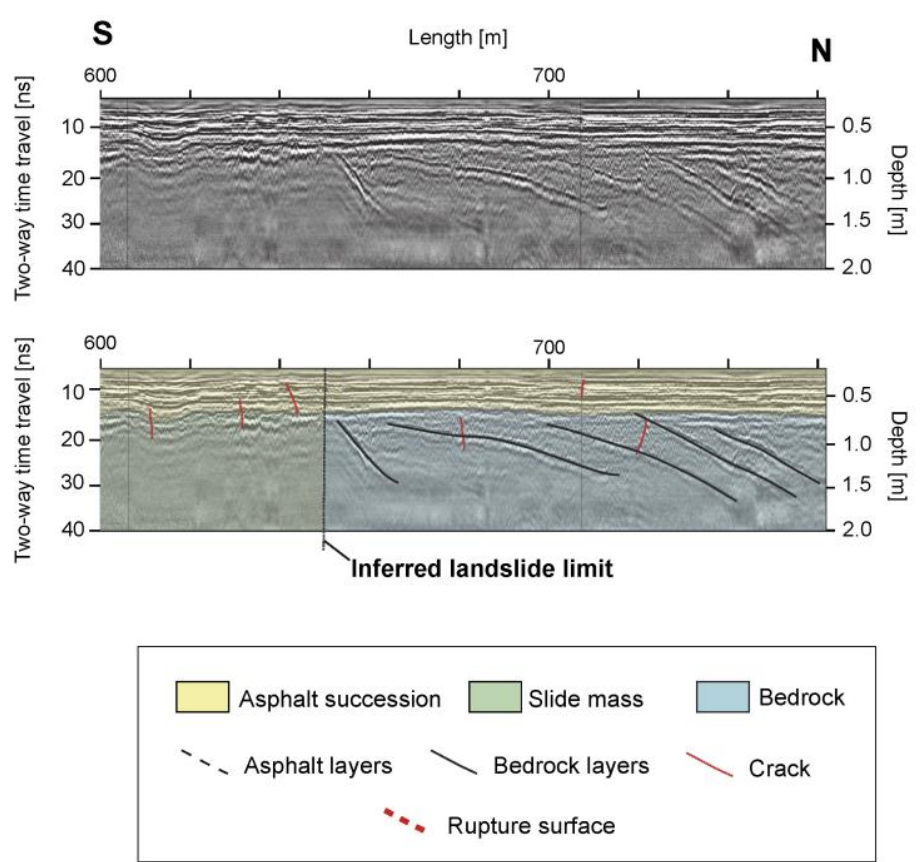

b) Profile "Transverse"
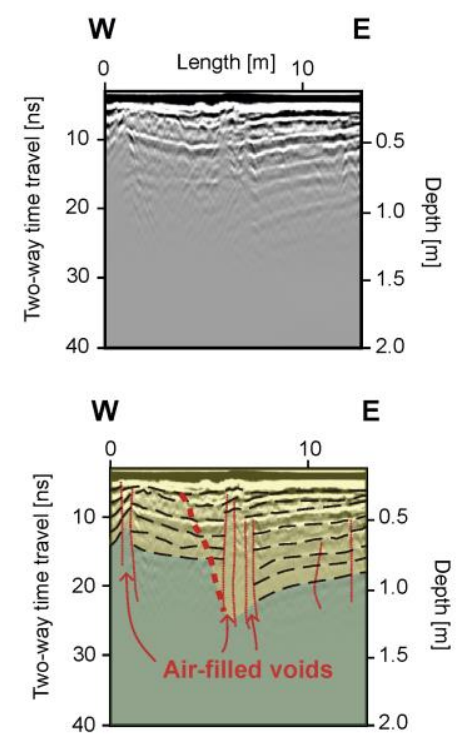

Fig. 14 a) Extract of the GPR Profile "East" (length from 600 to $760 \mathrm{~m}$ ). b) GPR Profile "Transverse". The location of the profile trace across the N-323 National Road is indicated in Fig. 13. 


\section{Discussion}

\subsection{Conditioning factors of the El Arrecife Landslide}

The understanding of the El Arrecife Landslide was made possible by the detailed analysis of the geological and structural setting, given that the geomorphology of the slope does not offer clear signs of the landslide type and characteristics. The great importance of the geological conditions, such as lithology or geological structure, in the El Arrecife Landslide generation has been demonstrated through this work. The slope is made up of phyllites, which represents the main conditioning factor for the landslides in the region, since around $40 \%$ of the areas where the Alpujárride Complex rocks are exposed is affected by landslides (El Hamdouni 2001; Chacón et al. 2003). Moreover, from the mechanical point of view, slopes formed by phyllites usually have a great potential to become unstable, due to the phyllites being coarse-grained rocks with a high mica content and a low friction angle (20-27ㅇ) (Roopnarine et al. 2013).

The El Arrecife Landslide is also clearly conditioned by the regional structure and the penetrative planar fabric of the phyllite rocks belonging to the Alpujarride Complex. Due to the deformation of these rocks (Simancas 2018 and references therein), changes in orientation of main foliation are expected. Such orientation variability leads to different kinematic scenarios that may, or may not, be conducive to sliding off a slope. For the El Arrecife Landslide case, a favourable planar failure scenario is defined within the landslide perimeter for the Set-1 'critical plane' orientation, in contrast to other plane orientations (i.e., Set-2 and Set-3) outside of the landslide perimeter.

\subsection{Estimated displacement rates of the El Arrecife Landslide}

The integration of multi-technique results has proved to be an effective procedure for a comprehensive view of the geometry and kinematics of slope movements, as evidenced by recent works: e.g. Janeras et al. 2016; Peduto et al. 2021; Cenni et al. 2021. For our case of study, the selected techniques provided valuable information on the El Arrecife Landslide displacement rate at very different time scales. While InSAR methods were used to obtain a short-term rate for a time scale of up to 5 years, SfM and GPR techniques made the estimation of two medium-term rates, respectively 14 and 22 years, possible. One of the main advantages of applying InSAR and SfM techniques is that they both take advantage of freely available images and follow automated procedures that can produce results in a few days. Moreover, all of these techniques can be applied and interpreted by different teams $100 \%$ dedicated to this task, in a matter of about two weeks. By using the provided information, a quick evaluation of the slope kinematics that affected a time span of a few decades could be performed.

The multi-technique study that was carried out within the El Arrecife Landslide made it possible to correlate all of the obtained rates to, then, complement and maximise the information provided by each method. Along the N-323 National Road, the subsidence rate obtained by the P-SBAS InSAR service $(1.5-2 \mathrm{~cm} / \mathrm{yr})$ can be almost correlated with the estimated rate from the GPR data $(1.4-2.3 \mathrm{~cm} / \mathrm{yr})$. On the contrary, the subsidence rate of up to $26 \mathrm{~cm} / \mathrm{yr}$, estimated from the SfM procedure, significantly differs from the InSAR and GPR rates. Such difference can be well explained by assuming that the slag heap could have been rapidly sliding during the first years after its construction, due to the initial typical compaction and overall shrinkage of the anthropic filling deposits (Barnes, 1995). Our InSAR results show a mean velocity of $3.6 \mathrm{~cm} / \mathrm{yr}$ in ascending orbit geometry in the slag heap area (Fig. 9), in contrast to a highest displacement rate of up to $5 \mathrm{~cm} / \mathrm{yr}$, presented by Reyes-Carmona et al. 2020. Such underestimation of the displacement may be related to the difference in the spatial resolution (i.e., pixel size) between both data: 14x4 m (Reyes-Carmona et al. 2020) versus the $90 \times 90 \mathrm{~m}$ obtained by the GEP InSAR service.

\subsection{Potential hazard of the El Arrecife Landslide}

Once a landslide is identified in a reservoir context, it is essential to discuss about the possibility of a rapid landslide acceleration, or reactivation, and a subsequent collapse of the slide mass into the reservoir. The most dangerous hazard being the generation of an impulse water wave (Gutiérrez et al. 2015). If the impulse wave overtops the reservoir dam, a massive flash flood 
could be generated downstream from the reservoir, as well as other devastating consequences, such as human and material damage in nearby towns, roads, or power lines among others. The acceleration of landslides is a complex topic under discussion within the scientific community, probably due to the large number of factors that determine the potential of acceleration: i) the volume of the landslide, ii) its velocity, iii) the shear strength of the failure surface, or iv) the resistance opposed by the reservoir water (Pinyol et al. 2012); among others. Even when considering just one influence factor, there is no agreement. As an example, with respect to the dip angle of failure, Gutiérrez et al. (2015) suggested the existence of a natural threshold around $20^{\circ}$ for the development of extremely rapid rockslides, capable of generating impulse water waves. By contrast, Glastonbury and Fell (2010) concluded that the inclination of the basal rupture surface could be as low as $5^{\circ}$. According to the volume of the landslide, it is also difficult to establish a well proven link with a critical acceleration possibility: the 1000 million $\mathrm{m}^{3}$ Mayunmaca rockslide in Peru (Kojan and Hutchinson 1978) and the 15 million $\mathrm{m}^{3}$ Guinsaugon rockslide in Philippines (Evans et al. 2007) both reached the same velocity, around $35 \mathrm{~m} / \mathrm{s}$. Under these uncertainties, the El Arrecife Landslide, that presents a surface of rupture dipping $21^{\circ}$ and a volume of 14.7 million $\mathrm{m}^{3}$, could be considered as a potential landslide for a fast sliding.

Despite the fact that there are no indicators of a catastrophic failure of the El Arrecife Landslide at present time, this does not imply that a rapid acceleration could not happen in the future (Pinyol et al. 2016). The aforementioned authors referenced several landslides with a relatively slow motion along pre-existing shearing surfaces prior to a sudden failure: the Grijalva landslide in Mexico (Alcántara-Ayala and Domínguez-Morales 2008), the Qianjiangping landslides in China (Wang et al. 2004; Dai et al., 2004), the Val Pola landslide (Govi et al. 2002), and the Sale mountain landslide (Zhang et al. 2002). The El Arrecife Landslide TS reveals a slow and constant movement of the slope with no indicators of a critical acceleration (Fig. 11), although, according to Reyes-Carmona et al. (2020), an acceleration of the whole landslide body is possible due to its translational character. Despite that, in our opinion the smaller-scale rotational landslides, located at the foot of the El Arrecife Landslide, are more likely to generate damage in the short-term. These rotational landslides have been disrupting the N-323 National Road during the past two decades, at least, as evidenced by GPR findings and field studies, resulting in a constant subsidence of the road and its deterioration. Moreover, the InSAR TSs revealed higher displacement rates within the El Arrecife Landslide's foot (i.e., Sectors 1,2 and 3 ), as well as a correlation between the acceleration of the movement and periods of decline of the reservoir water level (Fig. 11). These findings will serve to develop the importance of a proper management of the Rules Reservoir water level, especially during water discharge operations. Additionally, one should keep in mind that this reservoir is in an active seismic region, with a Peak Ground Acceleration (PGA) of up to $0.2 \mathrm{~g}$ (IGN-UPM 2015), which means that earthquakes could reach intensities of up to VIII, according to the European Macroseismic scale (IGN-UPM 2002). These accelerations in unstable slopes could provoke their failure, as evidenced by other worldwide examples of earthquake-triggered landslides: e.g. Rodríguez et al. 1999; Boomer et al. 2002; Khazai and Sitar, 2004; Gorum et al. 2011. For this reason, the catastrophic failure of the whole landslide, or of one of its sectors, are possible scenarios that must be taken into consideration. Regarding the latter scenario, detecting rapid accelerations that may be pre-failure precursors of a landslide is still a challenging task for the research community. Some recent studies demonstrate that InSAR is a suitable displacement monitoring technique for the recognition of such accelerations (Solari et al. 2018; Dong et al. 2018). Moreover, in case of critical acceleration, it is possible to forecast the time of slope failure by using the Inverse Velocity Method (IVM), developed by Fukozono 1985. The IVM has been effectively applied to several landslides (e.g. Segalini et al. 2019) and it has also provided satisfactory forecasting results when using InSAR data (Casagli et al. 2017; Carlà et al. 2017; Moretto et al. 2017; Intrieri et al. 2018 or Carlà et al. 2019). For the correct implementation of the IVM to identify possible accelerations, the monitoring activity should be constant in time and continued for as long as possible (Valletta et al. 2020). In this sense, the Geohazards Exploitation Platform (GEP) offers the chance to obtain daily InSAR results, and it could be a promising tool for the continuous monitoring of the El Arrecife Landslide's activity. However, it is our opinion that other InSAR procedures should also be applied to confirm GEP applicability. Also, it is our recommendation that in-situ measurement techniques, such as inclinometers or 
GPS, among others, must be applied. These conventional methods provide relevant information not only for validating remotely obtained displacement data, but also for their use as an early warning system (Chae et al. 2017). As a paradigmatic example, the Las Torres del Irazú Landslide (Costa Rica) proved the effectiveness of the application of GPS real-time monitoring to successfully forecast the time of failure (August 2020) by using the IVM (Muller et al. 2021).

Lastly, it is our opinion that an inclinometer survey should be carried out to confirm and precisely define the depth of the surface of rupture of the El Arrecife Landslide, and also monitor its movement. This information is necessary for a more precise estimation of its volume, an essential determining factor to correctly assess the landslide-related hazard (e.g., modelling of an impulse wave in case of landslide collapse). Our study will help in decisions related to where and how deep to drill.

\section{Conclusions}

The geological and motion data presented in this study highlight the relevance of the El Arrecife Landslide, an extremely large landslide located in an artificial reservoir context. The compiled geological data indicates an estimated possible surface of failure dipping $21^{\circ}$, and a landslide volume of 14.7 million $\mathrm{m}^{3}$. Furthermore, the lithology and the geological structure have been established as being the main conditioning factors. Moreover, the landslide kinematics have been defined as an overall translational movement oblique to the slope, together with a rotational movement within the landslide foot. The translational character could imply a potential hazard of fast sliding and collapse of the whole landslide within the reservoir, which would have devastating consequences. Despite this, the rotational movement within the landslide foot is more likely to generate damage in the short-term, especially along the N-323 National Road.

The multi-technique monitoring employed revealed that the El Arrecife Landslide has been active at least since the last two decades: InSAR provided information for a period up to the last 5 years, while SfM and GPR registered information during 14 and 22 years, respectively. The vertical subsidence of the landslide obtained from InSAR techniques $(1.5-2 \mathrm{~cm} / \mathrm{yr})$, and estimated from GPR information $(1.4-2.3 \mathrm{~cm} / \mathrm{yr})$ can be almost correlated. SfM provided a higher subsidence rate of $26 \mathrm{~cm} / \mathrm{yr}$ in a small sector of the landslide foot, due to the existence of a slag heap. The main advantage of these techniques is that results can be provided in a quick and easy way by using already registered information, which is essential to evaluate the landslide hazard in case of an alarm situation. Moreover, combining different methods is key to complement the information obtained by each technique, improving confidence in the estimated values.

Finally, it is our recommendation to apply other remote and in-situ techniques for a continuous monitoring of the El Arrecife Landslide. InSAR and GPS are suitable methods for real-time monitoring and also for predicting a possible time of failure, in case of a rapid acceleration of the landslide. On the other hand, other in-situ methods should be carried out, such as inclinometers or drilling surveys, to confirm the depth of the failure surface and the volume of the landslide. These attributes are essential for further modelling of the slope, as well as for an accurate landslide hazard assessment. For such purpose, our geological study offers a preliminary characterisation of the landslide that may guide and optimise the planning of future surveys.

\section{Acknowledgements}

This work was mainly supported by the European Regional Development Fund (ERDF) through the project "RISKCOAST" (SOE3/P4/E0868) of the Interreg SUDOE Programme. The work of J.P.G., M.M-S., P.R. and J.M.A. was also supported by the "Ramón y Cajal" Programme (RYC2017-23335) of the Spanish Ministry of Science, the project "MORPHOMED" - PID2019107138RB-I00 / SRA (State Research Agency / 10.13039/501100011033) and the project "RADANDALUS" (P18-RT-3632) and B-RNM-305-UGR1818 of the FEDER / Junta de Andalucía-Consejería de Transformación Económica, Industria, Conocimiento y Universidades. The access to the Geohazard Exploitation Platform (GEP) of the European Space Agency (ESA) was provided by the Early Adopters Programme. The authors wish to thank the Road State Demarcation for providing valuable information and testimonies. The authors are grateful 
to Cristina Accotto and Alejandro Ruiz-Fuentes for the assistance on the structural geology interpretations. The authors also thank Dr. Lorenzo Valetti for the language revision.

\section{References}

AgiSoft Metashape Professional (Version 1.7.1) (Software) (2021). Retrieved from https://www.agisoft.com/downloads/installer/

Alcántara-Ayala I, Domínguez-Morales L, (2008) The San Juan de Grijalva catastrophic landslide, Chiapas, Mexico: lessons learnt. In: Casagli N, Fanti, R, Tofani V (eds) Web Proceedings of the First World Landslide Forum. Tokyo, pp 96-99

Aldaya F, Díaz de Federico A, García-Dueñas V, Martínez-García E, Navarro-Vilá F, Puga E (1979) Lanjarón - Geological Map of Spain 1:50000. Geological Survey of Spain, Madrid

Azañón JM, Goffé B (1997) Ferro- and magnesiocarpholite assemblages as record of high-P, low-T metamorphism in the central Alpujárrides, Betic Cordillera (SE Spain). Eur J Mineral 9: 1035-1051

Balanyá JC, García-Dueñas V, Azañón JM (1997) Alternating contractional and extensional events in the Alpujárride nappes of the Alboran domain (Betics, Gibraltar arc). Tectonics 16: 226-238

Barnes G (2016) Soil mechanics: principles and practice. Macmillan International Higher Education, London

Barra A, Solari L, Béjar-Pizarro M, Monserrat O, Bianchini S, Herrera G, Crosetto M, Sarro R, González-Alonso E, Mateos RM, Ligüerzana S, López C, Moretti S (2017) A methodology to detect and update active deformation areas based on Sentinel-1 SAR images. Remote Sens 9: 1002. https://doi.org/10.3390/rs9101002

Béjar-Pizarro M, Notti D, Mateos RM, Ezquerro P, Centolanza G, Herrera G, Bru G, Sanabria M, Solari L, Duro J, Fernández J (2017) Mapping Vulnerable Urban Areas Affected by SlowMoving Landslides Using Sentinel-1 InSAR Data. Remote Sens 9: 876. https://doi.org/10.3390/rs9090876

Brunner F, Zobl F, Gassner, G (2003) On the Capability of GPS for Landslide Monitoring. Felsbau 21: 51-54

Carlà T, Farina P, Intrieri E, Botsialas K, Casagli N (2017) On the monitoring and early-warning of brittle slope failures in hard rock masses: examples from an open-pit mine. Eng Geol 228:7181. https://doi.org/10.1016/j.enggeo.2017.08.007

Carlà T, Intrieri E, Raspini F, Bardi F, Farina P, Ferretti A, Colombo D, Novali F, Casagli N (2019) Perspectives on the prediction of catastrophic slope failures from satellite InSAR. Sci Rep 9: 1-9. https://doi.org/10.1038/s41598-019-50792-y

Casagli N, Frodella W, Morelli S, Tofani V, Ciampalini A, Intrieri E, Raspini F, Rossi G, Tanteri L, Lu P (2017) Spaceborne, UAV and ground-based remote sensing techniques for landslide mapping, monitoring and early warning. Geoenviron Disasters 4: 1-23. https://doi.org/10.1186/s40677-017-0073-1

Cenni N, Fiaschi S, Fabris M (2021) Integrated use of archival aerial photogrammetry, GNSS, and InSAR data for the monitoring of the Patigno landslide (Northern Apennines, Italy). Landslides 1-17. https://doi.org/10.1007/s10346-021-01635-3

Chacón J, Irigaray T, Fernández T (2007) Los movimientos de ladera de la provincia de Granada. In: Ferrer M (ed) Atlas Riesgos Naturales en la Provincia de Granada, 1st edn. Diputación de Granada-Geological Survey of Spain, Madrid, pp 45-82

Chae B G, Park HJ, Catani F, Simoni A, Berti M (2017) Landslide prediction, monitoring and early warning: a concise review of state-of-the-art. Geosci J 21: 1033-1070. https://doi.org/10.1007/s12303-017-0034-4 
Clague JJ, Stead D (2012) Landslides: types, mechanisms and modelling. Cambridge University Press, Cambridge

Conyers LB (2015) Analysis and interpretation of GPR datasets for integrated archaeological mapping. Near Surf. Geophys 13: 645-651

Corominas J, Moya J, Lloret A, Gili JA, Angeli MG, Pasuto A, Silvano S (2000) Measurement of landslide displacements using a wire extensometer. Eng Geol 55: 149-166. https://doi.org/10.1016/S0013-7952(99)00086-1

Cruden DM, Varnes DJ (1996) Landslide types and processes. In: Turner AK, Schuster RL (eds) Landslides investigation and mitigation. Transportation Research Board, Washington DC, Special Report 247, Chapter 3, pp 36-75

Dai FC, Deng JH, Tham LG, Law KT, Lee CF (2004) A large landslide in Zigui County, Three Gorges area. Can Geotech J 41: 1233-1240

Dong J, Zhang L, Li M, Yu Y, Liao M, Gong J, Luo H (2018) Measuring precursory movements of the recent Xinmo landslide in Mao County, China with Sentinel-1 and ALOS-2 PALSAR-2 datasets. Landslides 15: 135-144. https://doi.org/10.1007/s10346-017-0914-8

Eltner A, Kaiser A, Castillo C, Rock G, Neugirg F, Abellán A (2016) Image-based surface reconstruction in geomorphometry-merits, limits and developments. Earth Surf Dyn 4: 359-389. https://doi.org/10.5194/esurf-4-359-2016

Estévez A, Delgado F, Sanz de Galdeano C, Martín-Algarra A (1985) Los Alpujárrides al sur de Sierra Nevada. Una revisión de su estructura. Mediterranea 4: 5-32

Evans SG, Guthrie RH, Roberts NJ, Bishop NF (2007) The disastrous 17 February 2006 rockslide-debris avalanche on Leyte Island, Philippines: a catastrophic landslide in tropical mountain terrain. Nat. Hazards Earth Syst. Sci. 7: 89-101. https://doi.org/10.5194/nhess-7-89$\underline{2007}$

Fernández T, Brabb E, Delgado F, Martin-Algarra A, Irigaray C. Estévez A, Chacón-Montero J (1997) Rasgos geológicos y movimientos de ladera en el sector Ízbor-Vélez Benaudalla de la cuenca del río Guadalfeo (Granada). Proceedings of the IV Simposio Nacional Sobre Taludes y Laderas Inestables, Granada, pp. 795-808

Fernández-Motril R (2013) La N-323: Una Carretera Abandonada Desde 2009. Newspaper 'Granada Hoy', Granada, Spain. https://www.granadahoy.com/granada/N-323-carreteraabandonada 0 744225838.html. Accessed October 2013

Fisher RB, Breckon TP, Dawson-Howe K, Fitzgibbon A, Robertson C, Trucco E, Williams CKI, (2013) Dictionary of Computer Vision and Image Processing. John Wiley \& Sons, New Yersey

Foumelis M, Papadopoulou T, Bally P, Pacini F, Provost F, Patruno J (2019) Monitoring Geohazards using on-demand and systematic services on ESA's Geohazards exploitation platform. IGARSS 2019-2019 IEEE International Geoscience and Remote Sensing Symposium, Yokohama, pp 5457-5460. https://doi.org/10.1109/igarss.2019.8898304

Fukuzono T (1985) A new method for predicting the failure time of a slope. Proceedings of the fourth international conference and field workshop on landslides, Tokyo, pp 145-150

Galve JP, Pérez-Peña JV, Azañón, JM, Closson D, Caló, Fabiana, Reyes-Carmona C, Jabaloy, A, Ruano P, Mateos RM, Notti D, Herrera G, Béjar-Pizarro M, Monserrat O, Bally P (2017) Evaluation of the SBAS InSAR Service of the European Space Agency's Geohazard Exploitation Platform (GEP). Remote Sens 9: 1291. https://doi.org/10.3390/rs9121291

Geophysical Survey Systems (GSSI) RADAN 7 (Software). (2012).

Glastonbury J, Fell R (2010) Geotechnical characteristics of large rapid rock slides. Can Geotech J 47: 116-132 
Gorum T, Fan X, van Westen CJ, Huang RQ, Xu Q, Tang C, Wang G (2011) Distribution pattern of earthquake-induced landslides triggered by the 12 May 2008 Wenchuan earthquake. Geomorphology 133: 152-167. https://doi.org/10.1016/i.geomorph.2010.12.030

Govi M, Gullà G, Nicoletti, PG (2002) Val Pola rock avalanche of July 28, 1987, in Valtellina (Central Italian Alps). Rev Eng Geol 15: 71-89.

Gullà, G, Peduto D, Borrelli L, Antronico L, Fornaro G (2017) Geometric and kinematic characterization of landslides affecting urban areas: the Lungro case study (Calabria, Southern Italy). Landslides 14: 171-188. https://doi.org/10.1007/s10346-015-0676-0

Günther A, Wienhöfer J, Konietzky H (2012) Automated mapping of rock slope geometry, kinematics and stability with RSS-GIS. Nat Hazards 61: 29-49

Gutiérrez F, Lucha P, Galve, JP (2010) Reconstructing the geochronological evolution of large landslides by means of the trenching technique in the Yesa Reservoir (Spanish Pyrenees). Geomorphology 124: 124-136. https://doi.org/10.1016/j.geomorph.2010.04.015

Gutiérrez F, Linares R, Roqué C, Zarroca M, Carbonel D, Rosell J, Gutiérrez M (2015) Large landslides associated with a diapiric fold in Canelles Reservoir (Spanish Pyrenees): Detailed geological-geomorphological mapping, trenching and electrical resistivity imaging. Geomorphology 241: 224-242. https://doi.org/10.1016/i.geomorph.2015.04.016

Hartley R, Zisserman A (2003) Multiple View Geometry in Computer Vision. Cambridge University Press, Cambridge

IGN-UPM (2002) Actualización de Mapas de Peligrosidad Sísmica de España 2002 (en valores de intensidad, escala EMS-98). Centro Nacional de Información Geográfica, Madrid

IGN-UPM (2015) Actualización de Mapas de Peligrosidad Sísmica de España 2012. Centro Nacional de Información Geográfica, Madrid

Intrieri E, Raspini F, Fumagalli A, Lu P, Del Conte S, Farina P, Allievi J, Ferretti A, Casagli N (2018) The Maoxian landslide as seen from space: detecting precursors of failure with Sentinel1 data. Landslides, 15: 123-133. https://doi.org/10.1007/s10346-017-0915-7

Jabaloy A, Galindo-Zaldívar J, González-Lodeiro F (1993) The Alpujárride-Nevado-Filábride extensional shear zone, Betic Cordillera, SE Spain. J Struct Geol 15: 555-569

Janeras M, Jara JA, Royan MJ, Vilaplana JM, Aguasca A, Fàbregas X, Gili JA, Buxó P (2017) Multi-technique approach to rockfall monitoring in the Montserrat massif (Catalonia, NE Spain). Eng geol 219: 4-20. https://doi.org/10.1016/j.enggeo.2016.12.010

Jol HM (2008) Ground penetrating radar theory and applications. Elsevier, Amsterdam

Khazai B, Sitar N (2004) Evaluation of factors controlling earthquake-induced landslides caused by Chi-Chi earthquake and comparison with the Northridge and Loma Prieta events. Eng Geol 71: 79-95. https://doi.org/10.1016/S0013-7952(03)00127-3

Kiersch GA (1964) Vaiont Reservoir disaster. Civ Eng 34: 32-40.

Kojan E, Hutchinson JD (1978) Mayunmarca rockslide and debris flow, Peru. In: Voight B (ed) Developments in Geotechnical Engineering, 14th vol. Elsevier, Amsterdam, pp. 315-353

Kraus K (1997) Photogrammetry Volume 2 Advanced Methods and Applications. Dümmler Verlag, Bonn

Lissak C, Maquaire O, Malet JP, Lavigne F, Virmoux C, Gomez C, Davidson R (2015) Groundpenetrating radar observations for estimating the vertical displacement of rotational landslides. Nat Hazards Earth Syst Sci 15: 1399-1406. https://doi.org/10.5194/nhess-15-1399-2015

Muller C, Pacheco J, Angarita M, Alvarado GE, Sánchez B, Avard G (2021) El deslizamiento de las Torres del Irazú del 2020 (Costa Rica): antecedentes, colapso y situación actual. 
Universidad Nacional de Costa Rica-Observatorio Vulcanológico y Sismológico de Costa RicaComisión Nacional de Emergencias. Technical Report, pp. 34

Schuster RL (1979) Reservoir-induced landslides. Bull. Int. Assoc. Eng. Geol. Bull. I'Assoc. Int. Géologie l'Ingénieur 20: 8-15. https://doi.org/10.1007/BF02591233

Solari L, Barra A, Herrera G, Bianchini S, Monserrat O, Béjar-Pizarro M, Crosetto M, Sarro R, Moretti S (2018) Fast detection of ground motions on vulnerable elements using Sentinel-1 InSAR data. Geomatics Nat Hazards Risk 9: 152-174. https://doi.org/10.1080/19475705.2017.1413013

Manunta M, Bonano M, Buonanno S, Casu F, De Luca C, Fusco A, Lanari R, Manzo M, Ojha, C, Pepe A, Zinno I (2016) Unsupervised parallel SBAS-DInSAR chain for massive and systematic Sentinel-1 data processing. Proceedings of the 2016 IEEE International Geoscience and Remote Sensing Symposium, Beijing, pp 3890-3893. https://doi.org/10.1109/igarss.2016.7730010

Martínez-Martínez JM, Soto JI, Balanyá JC (2002) Orthogonal Folding of Extensional Detachments: Structure and Origin of the Sierra Nevada Elongated Dome (Betics, SE Spain). Tectonics 21: 1-3. https://doi.org/10.1029/2001TC001283

Martínez-Martínez JM, Soto JI, Balanyá JC (2004) Elongated domes in extended orogens: a mode of mountain uplift in the Betics (Southeast Spain). Geol Soc A Spec Pap 380: 243-266

Massonnet D, Feigl KL (1998) Radar interferometry and its application to changes in the earth's surface. Rev Geophys 36: 441-500. https://doi.org/10.1029/97RG03139

Moretto S, Bozzano F, Esposito C, Mazzanti P, Rocca A (2017) Assessment of landslide prefailure monitoring and forecasting using satellite SAR interferometry. Geosciences 7: 36. https://doi.org/10.3390/geosciences 7020036

Niethammer U, James MR, Rothmund S, Travelletti J, Joswig M (2012) UAV-based remote sensing of the Super-Sauze landslide: Evaluation and results. Eng Geol 128: 2-11. https://doi.org/10.1016/i.enggeo.2011.03.012

Notti D, Herrera G, Bianchini S, Meisina C, García-Davalillo JC, Zucca F (2014) A methodology for improving landslide PSI data analysis. Int $J$ Remote Sens 35: 2186-2214. https://doi.org/10.1080/01431161.2014.889864

Pathak S, Nilsen B (2004) Probabilistic rock slope stability analysis for Himalayan conditions. Bull Eng Geol Environ 63: 25-32. https://doi.org/10.1007/s10064-003-0226-1

Peduto D, Santoro M, Aceto L, Borrelli L, Gullà G (2021) Full integration of geomorphological, geotechnical, A-DInSAR and damage data for detailed geometric-kinematic features of a slowmoving landslide in urban area. Landslides 18: 807-825. https://doi.org/10.1007/s10346-020$\underline{01541-0}$

Pinyol NM, Alonso EE, Corominas J, Moya J (2012) Canelles landslide: modelling rapid drawdown and fast potential sliding. Landslides 9: 33-51. https://doi.org/10.1007/s10346-011$\underline{0264-x}$

Pinyol NM, Alonso EE, Corominas J, Moya J (2016) Discussion on 'Large landslides associated with a diapiric fold in Canelles reservoir (Spanish Pyrenees): Detailed geologicalgeomorphological mapping, trenching and electrical resistivity imaging' by Gutiérrez et al. (2015). Geomorphology 263: 170-174. https://doi.org/10.1016/i.geomorph.2015.11.016

Poisel R, Angerer H, Pöllinger M, Kalcher T, Kittl H (2009) Mechanics and velocity of the Lärchberg-Galgenwald landslide (Austria) Eng Geol 109: 57-66. https://doi.org/10.1016/i.enggeo.2009.01.002

Regmi AD, Yoshida K, Nagata H, Pradhan AMS, Pradhan B, Pourghasemi HR (2013) The relationship between geology and rock weathering on the rock instability along MuglingNarayanghat road corridor, Central Nepal Himalaya. Nat Hazards 66: 501-532 
Reyes-Carmona C, Barra A, Galve JP, Monserrat O, Pérez-Peña JV, Mateos RM, Notti D, Ruano P, Millares A, López-Vinielles J, Azañón JM (2020a) Sentinel-1 DInSAR for Monitoring Active Landslides in Critical Infrastructures: The Case of the Rules Reservoir (Southern Spain). Remote Sens 12: 809. https://doi.org/10.3390/rs12050809

Reyes-Carmona C, Galve JP, Barra A, Monserrat O, Mateos RM, Azañón JM, Pérez-Peña JV, Ruano P (2020b) The Sentinel-1 CNR-IREA SBAS service of the European Space Agency's Geohazard Exploitation Platform (GEP) as a powerful tool for landslide activity detection and monitoring. EGU General Assembly Conference Abstracts, pp 19410. https://doi.org/10.5194/egusphere-egu2020-19410

Riquelme A, Del Soldato M, Tomás R, Cano M, Bordehore LJ, Moretti S (2019) Digital landform reconstruction using old and recent open access digital aerial photos. Geomorphology 329: 206-223. https://doi.org/10.1016/i.geomorph.2019.01.003

Rocscience DIPS (Software) (2004). Rocscience Inc., Toronto.

Rodriguez CE, Bommer JJ, Chandler RJ (1999) Earthquake-induced landslides: 1980-1997. Soil Dyn Earthq Eng 18: 325-346. https://doi.org/10.1016/S0267-7261(99)00012-3

Roopnarine R, Eudoxie G, Opadeyi J (2013) Soil friction angle as an instability factor in landslide susceptibility modelling. Soil Dyn Earthq Eng 3: 55-71

Segalini A, Carri A, Valletta A, Martino M (2019) Innovative monitoring tools and early warning systems for risk management: A case study. Geosciences 9: 62. https://doi.org/10.3390/geosciences9020062

Simancas JF (2018) A reappraisal of the Alpine structure of the Alpujárride Complex in the Betic Cordillera: Interplay of shortening and extension in the westernmost Mediterranean. J Struct Geol 115: 231-242. https://doi.org/10.1016/i.jsg.2018.08.001

Simancas JF, Campos J (1993) Compresión NNW-SSE tardi a postmetamórfica y extensión subordinada en el Complejo Alpujárride (Dominio de Alborán, Orógeno Bético). Rev. Soc. Geol. España 6: 23-35

Snavely N, Seitz SM, Szeliski R (2008) Modeling the world from internet photo collections. Int J Comput Vis 80: 189-210

Spanilá T, Horsky O, Banach M (2002) Slides and sliding in the water reservoirs banks. In: Rybár J, Stemberk J, Wagner P (eds) Landslides: Proceedings of the First European Conference on Landslides. CRC Press, Boca Ratón, pp. 315

Szeliski R (2010) Computer Vision: Algorithms and Applications. Springer Science and Business Media, Berlin

Tapete D, Cigna F (2017) InSAR data for geohazard assessment in UNESCO World Heritage sites: State-of-the-art and perspectives in the Copernicus era. Int J Appl Earth Obs Geoinf 63: 24-32. https://doi.org/10.1016/i.jag.2017.07.007

Teza G, Galgaro A, Zaltron N, Genevois R (2007) Terrestrial laser scanner to detect landslide displacement fields: A new approach. Int $J$ Remote Sens 28: 3425-3446. https://doi.org/10.1080/01431160601024234

Ullman S (1979) The Interpretation of Visual Motion. Massachusetts Instituto of Technology, Massachusetts

Valletta A, Segalini A, Carri A (2020) Application of a Generalized Criterion: Time-of-Failure Forecast and Alert Thresholds Assessment for Landslides. In: De Mario M, Tiwari AK (eds) Applied Geology. Springer, Cham, pp 283-298. https://doi.org/10.1007/978-3-030-43953-8 17

Wang FW, Zhang YM, Huo AT, Matsumoto T, Huang BT (2004) The July 14, 2003 Qianjiangping landslide, Three Gorges Reservoir, China. Landslides 1: 157-162. https://doi.org/10.1007/s10346-004-0020-6 
Westoby MJJ, Brasington J, Glasser NFF, Hambrey MJJ, Reynolds JMM (2012) Structure-frommotion photogrammetry: a low-cost, effective tool for geoscience applications. Geomorphology 179: 300-314. https://doi.org/10.1016/i.geomorph.2012.08.021

Wyllie DC, Mah C (2004) Rock slope engineering. CRC Press, Boca Ratón

Zhang ZY, Chen SM, Tao LJ (2002) 1983 Sale mountain landslide, Gansu Proince, China. Rev Eng Geol 15: 149-163 